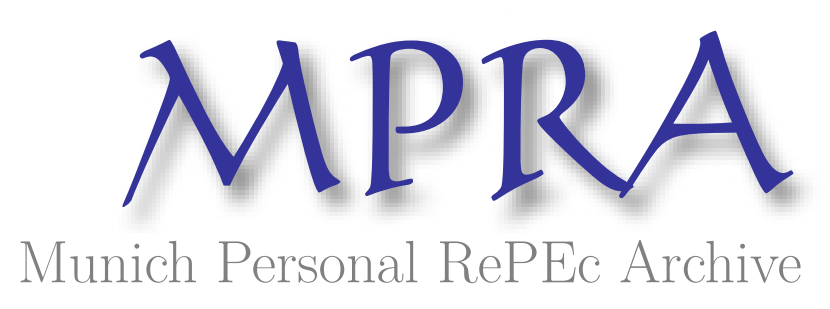

\title{
Racial Residential Segregation and Black Low Birth Weight, 1970-2010
}

Niemesh, Gregory and Shester, Katharine

16 May 2019

Online at https://mpra.ub.uni-muenchen.de/93972/

MPRA Paper No. 93972, posted 23 May 2019 09:27 UTC 
RACIAL RESIDENTIAL SEGREGATION AND BLACK LOW BIRTH WEIGHT, 1970-2010

\author{
Gregory T. Niemesh \\ Miami University and NBER \\ and \\ Katharine L. Shester \\ Washington and Lee University
}

\begin{abstract}
The black-white gap in low birth weight in the United States remains large and mostly unexplained. A large literature links segregation to adverse black birth outcomes but, to the best of our knowledge, no studies explore how this relationship has changed over time. We explore the relationship between racial residential segregation on black and white birth weights for the period 1970-2010. We find a negative effect of segregation on black birth outcomes that only emerges after 1980. We explore the potential pathways through which segregation influenced black birth outcomes and how these mechanisms may have changed over time. Measures for maternal socioeconomic status and behaviors accounts for 35 to 40 percent of the full segregation effect between 1990 and 2010. Single-motherhood and mother's education, and unobservable factors that load onto these variables, play important and increasing roles. After controlling for MSA and parent characteristics, segregation explains 21-25 percent of the raw black-white gap in low birth weight between 1990 and 2010.
\end{abstract}

Keywords: Racial segregation, residential segregation, low birth weight, infant health JEL Codes: J13, J15, I14, R23

Niemesh: Assistant Professor of Economics, Miami University, Department of Economics, and NBER, niemesgt@miamioh.edu, 800 E. High Street, Oxford, OH 45056, (P) 513.529.2150, (F) 513-529-6992. Shester: Associate Professor of Economics, Washington and Lee University, Department of Economics, shesterk@wlu.edu, 204 W. Washington St., Lexington, VA, 24450. Acknowledgements: We are particularly thankful to Jonathan Fox, Christopher Handy, Caitlyn Knowles Myers, Edgar O. Olsen, and Evan Roberts. We would also like to thank participants at the 2015 annual meetings of the Social Science History Association, the 2015 AALAC

Conference on the economic history of race, gender, and class, the 2016 annual meetings of the Population Association of America, and the 2016 annual meetings of the Southern Economics Association. John Juneau II, Margaret Kallus, Will Schirmer, and Amanda Wahlers provided excellent research assistance. 
Despite vast improvements in public health and healthcare throughout the $20^{\text {th }}$ century, a large black-white gap in infant health remains and goes largely unexplained (Lhila and Long 2011). In 2015, black mothers were 1.9 times as likely to give birth to a low birth weight child as a white mother (13.4 percent, compared to 6.9). ${ }^{1}$ This gap has remained virtually unchanged since 1970, when the percentage of births to black mothers less than 2,500 grams was 13.9 percent, compared to 6.8 percent. $^{2}$ Of the multitude of factors driving the racial difference in birth outcomes, racial residential segregation is often emphasized in the literature on social determinants of health (Polednak 1996; Bird 1995; Laveist 1993; Polednak 1991; Osypuk 2008; Ellen 2000). Williams and Collins (2001) argue that "racial and residential segregation is the cornerstone on which black-white disparities in health status have been built in the U.S."

While a large literature links levels of residential racial segregation to negative health outcomes for black infants for a single period of time (e.g., Britton and Shin 2013; Bell et al. 2006; Hearst et al. 2008; Kramer and Hogue 2008; Kramer et al. 2010), the majority of studies make within-city comparisons, addressing the question of whether blacks living in high percentage black neighborhoods have better birth outcomes than blacks living in neighborhoods that are more integrated (e.g., Debbink and Bader 2011; Roberts 1997; Pickett et al. 2005; Grady 2006 and 2010; Guest et al. 1998). ${ }^{3}$ However, such comparisons could magnify or mask the true

\footnotetext{
${ }^{1}$ https://www.cdc.gov/nchs/data/nvsr/nvsr66/nvsr66_01.pdf; https://www.cdc.gov/nchs/data/hus/2015/011.pdf

${ }^{2} \mathrm{https}: / /$ www.cdc.gov/nchs/data/nvsr/nvsr61/nvsr61_01.pdf; https://www.census.gov/prod/2/gen/96statab/vitlstat.pdf

${ }^{3}$ In this paper, we focus solely on the non-hispanic black-white gap in low birth weight. But we, acknowledge that births to other races/ethnicities made up an increasingly large share of all births over the time period under study. By 2017, births to mothers of other races and ethnicities made up 33 percent of total births, of which 23 percent were to Hispanic mothers (Mathews and Hamilton 2018).
} 
effects of segregation. For example, sorting across neighborhoods might naturally lead to black residents with higher socioeconomic status (and possibly better health outcomes) choosing to live in more integrated neighborhoods, biasing estimates of the within-city effect of segregation upward. Alternatively, the intra-city comparison might result in a downward bias if segregation negatively impacts all black residents within a city, not just those living in predominantly black areas. An exception to this critique is Ellen (2000), which uses cross-city variation in segregation and finds evidence of negative effects on black low birth weight, but no effect on white birth weight.

We build on Ellen (2000)'s work by extending the analysis to changes in the relationship between segregation and low birth weight between 1970 and 2010. Describing when and where the negative relationship emerged helps researchers better understand its underlying causes. Our results are broadly consistent with segregation having no effect on the birth outcomes of white mothers throughout the period. For black mothers, we find no association between segregation and low birth weight in 1970 or 1980, but a large, positive, and persistent link between segregation and low birth weight by 1990 . For 1990, 2000, and 2010, a one standard deviation increase in segregation is associated with a 3.6-4.5 percent increase in black low birth weight relative to the mean.

After documenting the rise of the association between segregation and low birth weight, we conduct a number of exercises to assess how strongly the association can be interpreted as causal. In our main regressions, we include MSA-level controls (interacted with race and year), MSA fixed effects, and region-by-race-by-year fixed effects. We then address issues of reverse causality or omitted variable bias by investigating whether our results are driven by past levels or contemporaneous changes in segregation. We find that base levels of segregation and recent 
changes are both associated with increased low birth weight for blacks between 1990 and 2010, which suggests that the results are not driven by differential changes in segregation levels across high and low birth weight areas. We also find no link between black low birth weight in 1970 and 1980 and future changes in segregation, which suggests that reverse causality is not driving our results.

To better understand why the relationship between segregation and black low birth weight changes over time we use a detailed set of parental characteristics and behaviors from individual birth certificate data. The accounting method of Gelbach (2016) allows us to estimate the contribution of parental characteristics and any observables that load onto that characteristic. Characteristics of the mother (marital status, prenatal care, education, age) and birth order account for 35-40 percent of the correlation between 1990 and 2010, with marital status and mother's education making the largest contribution. Even after controlling for the direct effects of these characteristics, the independent effect of segregation on black low birth weight is substantial, explaining 21-25 percent of the black-white gap between 1990 and 2010.

\section{Background}

\section{A. The Importance of Birth Weight and Causes of Low Birth Weight}

In the economics literature, birth weight is viewed both as an output of the infant health production function and also as an input for later-life outcomes (e.g., health, educational attainment, income). A vast literature finds that a number of infant, child, and adult outcomes are correlated with birth weight, with many studies finding evidence of a causal link. For example, low birth weight infants are at a higher risk for infant mortality (Conley and Bennett 2001; Oreopolous et al. 2008), and children born with low birth weight have lower schooling 
attainment (Black, Devereaux, and Salvanes 2007; Case and Paxson 2010; Royer 2009;

Oreopolous et al 2008) and lower test scores (Figlio et al. 2014). ${ }^{4}$ The effects of low birth weight can extend into adulthood with lower earnings (Behrman and Rosenzweig 2004), increased receipt of social assistance payments (Oreopolous et al. 2008), poorer health (Barker 1995; Curhan et al. 1996), and low birth weight in the next generation (Currie and Moretti 2007).

The long reach of low birth weight into adulthood provides a potential avenue to address racial disparities in economic and physical well-being in the United States today. Interventions to reduce the disparity in birth weight have the potential to reduce disparities in other socioeconomic indicators, such as educational attainment and earnings.

The proximate causes of low birth weight are well known but seemingly tautological: low intra-uterine growth during gestation or young gestational age. Major culprits can be divided into two general categories: pre-pregnancy maternal factors and maternal factors during pregnancy. The mother brings an initial level of health capital to the infant health production function. Therefore, factors like socioeconomic status, early life health, stressors, environment, and behaviors that affect a mother's general health may lead to low birth weight. Many of these same factors impact birth weight during the pregnancy, either directly (environment, health behaviors, stressors) or indirectly (socioeconomic status through behaviors and constraints). The literature on birth weight focuses on a variety of contributors, such as the use of illicit substances (Fertig and Watson 2009, Evans and Ringel 1999, Jacobson, et al. 1994, Noonan, Reichman, Corman, and Dave 2007), safety net programs (Hoynes, Page, and Stevens 2011), mother's education (Currie and Moretti 2003), and environmental conditions (Currie and Walker 2011, Currie, Neidell, and Schmieder 2009, Currie and Schmieder 2009). Maternal stress during pregnancy has

\footnotetext{
${ }^{4}$ A newborn weighing less than 2,500 grams is considered to be of low birth weight.
} 
also been shown to reduce birth weight (Catalano and Hartig 2001; Lauderdale 2006; Torche 2011).

\section{B. Residential Segregation and Low Birth Weight}

Residential racial segregation may have adverse effects on birth weight by leading mothers to have more or less of any of the factors discussed above. For example, segregation may affect infant health by changing a variety of social and economic outcomes. Previous work by Cutler and Glaeser (1997) and Ananat (2011) finds that segregation leads to lower educational attainment and income and higher rates of single motherhood among black residents. Lower educational attainment may lead to worse infant health if it makes women less able to afford prenatal care, increases stress, or causes women to have inferior information about pregnancy health (Currie and Moretti 2003, Ellen 2000). Marital status has also been found to be highly correlated with birth outcomes, which may be due to its relationship with income (e.g., lowincome women are less likely to be married) or unexpected pregnancies (Buckles and Price 2013). However, while segregation has been found to be linked with lower socioeconomic status, this relationship is a relatively new phenomenon. Collins and Margo (2000) find that the adverse relationship between segregation and socioeconomic outcomes such as income and single motherhood developed in the 1970s and strengthened in the 1980s. Therefore, to the extent that segregation's effect on infant health works through this socioeconomic channel, segregation may have had a less adverse effect on low birth weight prior to 1990.

Segregation may also influence infant health through its effects on women's behavior during pregnancy. This could work through reduced access to medical care or healthy food options, which may reduce prenatal care and nutritional quality during pregnancy. Or, 
segregation may reduce exercise during pregnancy if segregation is associated with higher crime rates or lower access to public goods such as gyms or parks. In this scenario, women in these cities may have fewer opportunities to exercise.

Segregation may have further effects on infant health through its effect on mothers' stress (Collins et al 2000; Ellen 2000). This may work through higher crime rates and increased unemployment and could have a direct effect on a woman's pregnancy by weakening her immune system (Hoffman and Hatch 1996) or an indirect effect if she copes with stress by adopting negative behaviors such as smoking or drinking (Moiduddin and Massey 2008). Finally, segregation may also influence birth outcomes and maternal health through exposure to environmental hazards (Ellen 2000). Predominantly black neighborhoods may be exposed to higher levels of pollution through proximity to factories and highways, or may have lower quality housing containing higher levels of mold, allergens, or vermin, all of which may have

adverse effects on infant health. ${ }^{5}$ To the extent that the effect of segregation on low birth weight is changing over time, however, the relationship between segregation and drug and alcohol use, or segregation and exposure to environmental toxins would also have to change over time for this to explain our results.

\section{Data}

We combine individual-level data on infant health at birth with MSA-level data on segregation and economic characteristics. The individual-level health data come from the National Vital Statistics System of the National Center for Health Statistics (NCHS 1970, 1971,

\footnotetext{
${ }^{5}$ Shertzer, Twinam, and Walsh (2016) find evidence of discriminatory zoning in Chicago in the early twentieth century, with black neighborhoods being more likely to receive zoning for high density residences and manufacturing.
} 
1980, 1981, 1990, 1991, 2000, 2001, 2010, 2011) and includes birth characteristics, such as birth weight, mother's marital status, parents' education, and county of residence. We are interested in birth outcomes in 1970,1980,1990, 2000, and 2010, and combine data with an adjacent year each decade to minimize noise from year-to-year variation. ${ }^{6}$ We begin our analysis with 1970 as the individual-level data is only available from 1968 onward.

We link the infant health data to MSA-level characteristics, including segregation, log population, percent black population, average family income, and percent of employment in manufacturing. We construct these variables for 1970-2010 by aggregating census tract-level data (accessed through Social Explorer 2016) to the MSA level. We limit our analysis to MSAs with a black population of at least 5,000 in a given year. The sample includes births to mothers whose race is identified as non-Hispanic white or black on the child's birth certificate. ${ }^{7}$ Our preferred specifications limit the sample to a balanced panel of 158 MSAs for which complete data exist for each decade, and which have a black population of at least 5,000 in all years.

We measure residential racial segregation with the dissimilarity index, which indicates the relative evenness of the racial distribution of residents across census tracts within a larger area such as an MSA. The dissimilarity index is defined as

$$
D_{M S A}=\frac{1}{2} \sum_{i=1}^{N}\left|\frac{B L A C K_{i}}{\text { BLACK }_{\text {total }}}-\frac{N O N B L A C K_{i}}{N O N B L A C K_{\text {total }}}\right| .
$$

Here, $B L A C K_{i}$ is the number of black residents in census tract $i$ and $B L A C K_{\text {total }}$ is the total black population in the MSA, with $N O N B L A C K_{i}$ and $N O N B L A C K_{\text {total }}$ defined similarly. The index

\footnotetext{
${ }^{6}$ We use data from 1970 and 1971 for 1970 , data from 1980 and 1981 for 1980 , etc.

${ }^{7}$ Hispanic origin is not identified in 1970 or 1980 , so we include all white and black births for these years.
} 
measures the share of the black (or nonblack) population that would need to move census tracts so that the racial composition (percent black) of each tract in the MSA is identical. The index ranges from 0 to 1 with a value below 0.3 generally considered a low level of dissimilarity, a value between 0.3 and 0.6 a moderate level, and above 0.6 a high level (Massey and Denton 1993 and 1998).

\section{A. Descriptive Statistics}

Summary statistics for low birth weight and segregation are reported in table 1 . A substantial racial gap in low birth weight exists in all years, with no notable improvements between 1970 and 2010 .

Table 1 also reports the propensity of low birth weight for MSAs in the top and bottom deciles of segregation in each year. Comparing the differences in averages between these two deciles, one can see only trivial differences for black and white birth outcomes in 1970. In 1980, however, the propensity of black low birth weight was 16 percent (1.9 percentage points) higher in MSAs in the highest segregation decile compared to those in the lowest decile. By 1990, the propensity of black low birth weight was 26 percent (3.0 percentage points) higher in MSAs in the highest segregation decile. This health disparity between high- and low-segregation MSAs declined in the $1990 \mathrm{~s}$, falling to 8 percent (1.0 percentage points) in 2000 and 13 percent (1.6 percentage points) in 2010 . For the white population, there was little difference in low birth weight between high and low segregation MSAs throughout the entire period.

Segregation, as measured by the dissimilarity index, declined during this period. Between 1970 and 2010, the median level of segregation fell from 0.75 to 0.47 . Similar declines occurred 
at both ends of the distribution, with the $25^{\text {th }}$ percentile falling from 0.66 to 0.40 , and the $75^{\text {th }}$ percentile falling from 0.81 to $0.56 .^{8}$

A first look at the correlation of segregation and low birth weight is shown in figure 1, which plots the percentage of white and black births less than 2,500 grams in each MSA against segregation by decade. We find no discernable relationship between low birth weight and segregation for whites in any year. For black mothers, however, a positive gradient emerges over time. In 1970 the slope is relatively flat, whereas by 1990 low birth weight is clearly increasing with the dissimilarity index, a relationship that persists to $2010 .^{9}$

\section{Empirical Strategy and Main Results}

\section{A. Empirical Strategy}

Our empirical strategy exploits the cross-MSA variation in segregation to assess the relationship between segregation and low birth weight $(L B W)$ and its evolution over time. We estimate the linear probability model in equation (1), where the dependent variable is an indicator for whether individual $i$ has a birth weight of less than 2,500 grams.

$$
\begin{aligned}
& \text { (1) } L_{B} W_{i}=\alpha+\beta_{1 t} \text { segregation }_{M S A, t}+\beta_{2 t} \text { segregation }_{M S A, t} * \text { Black }_{i}+\gamma_{t}+ \\
& X_{M S A, t}{ }^{\prime} \theta_{t}+\delta_{r, t}+\left(\gamma_{t, \text { black }}+X_{M S A, t^{\prime}} \theta_{t, \text { black }}+\delta_{r, t, \text { black }} * \text { Black }_{i}\right)+\Gamma_{M S A}+\varepsilon_{i}
\end{aligned}
$$

\footnotetext{
${ }^{8}$ Appendix tables A1 and A2 list the ten MSAs with the highest and lowest levels of segregation in each decade.

${ }^{9}$ Appendix table A3 lists the five MSAs with the highest incidence black low birth weight, highest incidence of white low birth weight, and the largest black-white gap in each decade. Appendix table A4 lists the MSAs with the lowest incidences of low birth weight and the smallest black-white gaps.
} 
Our primary variable of interest is the level of segregation (segregation), as measured by the dissimilarity index in individual $i$ 's metropolitan area of birth (MSA) in the year in which the birth occurred $(t) .{ }^{10}$ We interact segregation with a set of year indicators and our race indicator, Black, to allow for the effect of segregation to differ for blacks and whites, and to change over time. We include year fixed effects $\left(\gamma_{t}\right)$ in all specifications and interact these with our race indicator. Some specifications include MSA-level controls, $X_{M S A, t}$, to capture time-varying city characteristics that might be correlated with segregation: log population, percent black population, percent manufacturing, and average family income in year $t$. We interact these controls with our year and race dummy variables to allow for these MSA characteristics to have different effects for whites and blacks, and over time. In other specifications, we also add regionby-year fixed effects, $\delta_{r, t}$ and MSA fixed effects, $\Gamma_{M S A}$.

Our coefficients of interest, $\beta_{1 t}$ and $\beta_{2 t}$, can be interpreted as follows: a 0.12 (approximately one standard deviation) increase in the dissimilarity index in year $t$ would be associated with a $0.12 * \beta_{1 t}$ percentage point increase in the probability of low birth weight for a white mother in year $t$, and a $0.12^{*}\left(\beta_{1 t}+\beta_{2 t}\right)$ percentage point increase in the probability of low birth weight for a black mother. Therefore, $\beta_{2 t}$ indicates the differential effect of segregation on births to black mothers as compared to white mothers.

This approach encounters three difficulties. First, omitted variable bias may remain even after conditioning on a set of controls meant to capture city-level characteristics. To help with this issue we focus on the estimate of $\beta_{2 t}$ as the causal effect for black mothers, using the effect on whites, $\beta_{1 t}$, to capture potential bias from city-wide unobservables common to both black and

\footnotetext{
${ }^{10}$ Results are similar for other segregation measures. We report results using the isolation index in appendix table A7.
} 
white births. Moreover, to the extent that we are interested in the change in $\beta_{2 t}$ over time, only a change in the relative omitted variable bias for black mothers compared to whites would threaten our interpretation.

Second, the measure of segregation might theoretically be endogenous and the product of reverse causation from within-MSA sorting. For example, poor labor market outcomes for black residents in an MSA, combined with income-based neighborhood sorting, might lead to a negative cross-MSA correlation between segregation and black incomes. Even in the absence of a causal effect of racial segregation, a correlation with low birth weight could be observed in this case because of the positive correlation between economic status and health outcomes. However, Cutler and Glaeser (1997) use an IV strategy to estimate the effect of segregation on black incomes and find estimates identical to their OLS estimates, suggesting that sorting based on labor market outcomes is not driving the relationship. Absent this type of within-MSA sorting, we do not believe that poor birth outcomes directly lead to racial sorting across neighborhoods (i.e., reverse causation). To test the potential role of omitted variable bias and endogeneity in our main results, we estimate additional regressions that break our segregation measure into previous levels and recent changes in segregation. This allows us to rule out a number of scenarios that could confound our results. For example, if unobservables were solely responsible for our main results, we might find that changes in segregation are correlated with changes in low birth weight, but previous levels of segregation are insignificant. We are able to rule out this scenario and estimate a falsification test to examine whether future changes in segregation predict low birth weight in earlier years to shed light on the possible role of reverse causality.

A final threat to a causal interpretation comes from possible cross-MSA sorting based on socioeconomic status. If individuals with worse birth outcomes choose to reside in MSAs with 
higher rates of segregation, we may find a spurious relationship between segregation and infant health. To the best of our ability, we rule out this potential bias by presenting evidence that rates of cross-MSA mobility by socioeconomic status are virtually identical between races and do not change over time.

\section{B. Results}

The first column of table 2 reports results from a parsimonious specification that includes segregation measures and race-specific year fixed effects. In the base specification, we find no meaningful relationship between segregation and low birth weight for white births in 1970, 1980, or 1990. For these years, the point estimates of $\beta_{1 t}$ range from -0.0056 to 0.0014 and are statistically insignificant. The $\beta_{2 t}$ coefficients indicate a different relationship between segregation and birth weight for black mothers. In the base specification, the point estimate on the segregation-black interaction term in 1970 is small and statistically insignificant at 0.011 , but increases to 0.034 in 1980 and 0.056 in 1990 (both statistically significant at the one percent level). This is consistent with the emergence of a segregation birth weight penalty for black mothers in the 1970s. However, the point estimate on the segregation-black interaction term decreases to 0.016 in 2000 and 2010 .

When we add MSA-level controls (by race and year), region fixed effects (by race), and/or MSA fixed effects (columns 2-5), the segregation-black interaction term for 1980 drops slightly but the interaction term for 1990 remains somewhat stable across specifications, ranging between 0.036 and 0.057 . Using the coefficients from column 5, a one standard deviation increase in segregation in 1990 is associated with a 0.005 percentage point, or 3.3 percent, increase in low birth weight for black mothers $((0.1283 \times 0.0363) / 0.1392)$. The point estimate on the interaction term is similar in 2000 and larger in 2010, remaining statistically significant 
with the addition of controls. Using the coefficients from column 5, a one standard deviation increase in segregation in 2010 is associated with a 0.006 percentage point, or 4.2 percent, increase in low birth weight for black mothers $((0.1176 \times 0.0474) / 0.1316)$. The magnitude of these results is large; multiplying the mean level of segregation in a given year with the coefficient on our segregation-black interaction term suggests that segregation explains 26-36 percent of the black-white gap in low birth weight between 1990 and 2010.

Results in columns (1)-(5) use data for individuals in the full sample of MSAs. However, some of the MSAs included in the sample are only available in a subset of years between 1970 and 2010, so it is possible that the results are being driven by changes in the composition of our sample over time. To address this concern, we re-estimate the specifications in columns (4) and (5), with a limited, but consistent, set of 158 MSAs that we observe in all five time periods. Results are reported in columns (6) and (7). The point estimates are little changed when limiting our sample to this consistent set of MSAs. The major difference between the results using our full and consistent samples is the point estimate on the segregation-black interaction term for 1980. Results using the consistent sample find no evidence of a link between segregation and black low birth weight until 1990, suggesting that this adverse relationship did not emerge until the 1980s. The difference in point estimates between the two early periods (1970 and 1980) and 1990 are statistically significant at the 5\% level, for 2000 and the $10 \%$ level, and for 2010 and the $5 \%$ level.

We also explore alternative measures of low birth weight, using a cutoff of 3,000 grams (6.6 pounds), 2,000 grams (4.4 pounds), 1,500 grams (3.3 pounds), and 1,000 grams (2.2 pounds). In appendix table A5, we report results from re-estimating specification (6) of table 2 with all of these measures as well as a continuous measure of birth weight in grams. We nearly 
always find statistically significant interactions between segregation and our black indicator variable for 1990-2010 when we define low birth weight thresholds between 1,500 and 3,000 grams and the size of these estimates is large: a one standard deviation increase in segregation is associated with a $0.7-7.2$ percent increase in the likelihood of low birth weight in 1990 and a 1.16.0 percent increase in the likelihood of low birth weight in 2010. Results using the continuous measure of birth weight are also consistent with segregation becoming associated with worse black infant health in the 1980s, increasing in magnitude from -89 in 1970 to -117 in 1990.

We also we test whether the results are driven by a general decline in measures of segregation across places by constructing a percentile rank measure of segregation levels across MSAs in each year. Because segregation rates fell in nearly all MSAs between 1970 and 2010, one might be concerned that being "highly segregated" was correlated with worse black infant health in all years, but as the dissimilarity index value associated with "high segregation" fell, the segregation coefficient mechanically increased. In appendix table A6, we report estimates from equation (1) this time using segregation percentiles instead of the dissimilarity index. We find that high percentiles of segregation are highly correlated with higher rates of low birth weight for black births in 1990, 2000, and 2010 in all specifications, and no evidence of similar effects of segregation on black low birth weight in 1970 or $1980 .{ }^{11}$

\section{Additional Robustness Checks}

The robustness of our results above to the inclusion of a variety of controls is striking. Still, several potential explanations for the relationship between segregation and low birth weight

\footnotetext{
${ }^{11}$ We also re-estimate table 2, using the isolation index measure of segregation instead of the dissimilarity index. Results are similar and are reported in appendix table A7.
} 
for black mothers remain. Before we test alternative explanations empirically, we begin by presenting a scatter plot of MSA-level segregation in 1970 and 2010. In figure 2, we find that the relationship between segregation in 1970 and in 2010 is remarkably linear. Segregation was higher in most places in 1970 than in 2010, however it changed in a very similar way across places.

While we find that segregation was very persistent over this period, the MSAs with the highest levels of segregation in 1970 and 2010 are noteworthy. Detroit, Milwaukee, Chicago, and Buffalo are all Rust Belt cities located in the upper right corner of figure 2, indicating high levels of segregation in both 1970 and 2010. It is possible that the decline in manufacturing that cities experienced after 1970 had a direct impact on economic and health outcomes during this period. In this scenario, the association between segregation and black low birth weight that we observe after 1990 may simply be the result of differential declines in manufacturing. The inclusion of MSA-level characteristics, such as percent manufacturing and average income, and region-year fixed effects in the results above mitigate these concerns somewhat, although omitted variable bias may still exist. We further address these potential concerns below.

\section{Base Levels of Segregation and Changes Over Time}

To explore the potential role of omitted variable bias, we regress our low birth weight indicator on segregation and the interaction between segregation and race, dividing our segregation measure into base levels (measured in an earlier decade) and recent changes. We estimate these regressions using one year of data at a time and control for MSA-level controls and region fixed effects, all interacted with an indicator for the birth being to a black mother. This is analogous to the specification reported in column 6 of table 2, as all of the controls in this 
pooled specification are interacted with year indicators. Equation (2) illustrates our specification, using 1990 as an example.

$$
\begin{gathered}
\text { (2) } L B W_{1990}=\alpha+\beta_{1} \text { segregation }_{M S A, 1970}+\beta_{2} \text { Segregation }_{M S A, 1970} * \text { Black }_{i}+ \\
\beta_{3} \Delta \text { segregation }_{M S A, 90-70}+\beta_{4} \text { segregation }_{M S A, 90-70} * \text { Black }_{i}+X_{M S A, 1990}{ }^{\prime} \theta+\delta_{r}+ \\
\left(X_{M S A, 1990} \theta_{\text {black }}+\delta_{r, \text { black }}\right) * \text { Black }_{i}+\varepsilon_{M S A, t}
\end{gathered}
$$

If the base results in table 2 are being driven by an omitted variable simultaneously causing changes in low birth weight and segregation, we would expect to find a strong link between recent changes in segregation and low birth weight between 1990 and afterward, but no link between former levels of segregation and 1990-2010 outcomes. Alternatively, if the results are being driven by changes in low birth weight in places with persistently high levels of segregation, we would expect former levels of segregation to be correlated with low birth weight in 1990-2010, but for recent changes in segregation to have little impact.

Panels A and B of table 4 report estimates using 1970 and 1980 as our base year. We estimate regressions for 1990, 2000, and 2010 separately and report results in columns 1-3. In columns 1 and 2, we find no statistically significant relationship between segregation (levels or changes) and the propensity of low birth weight for white mothers in 1990 and 2000, regardless of our choice of base year. In 2010, the point estimates on the change in segregation are 0.0290.036 depending on our choice of base year and are statistically significant, suggesting that white birth outcomes were worse in places experiencing relative increases in segregation.

The coefficients on the interaction terms between our black indicator and our two measures of segregation (changes and levels) for these three decades are positive and usually 
statistically significant. In most of these regressions, the point estimates on the interaction of Black and segregation and on the interaction of Black with Asegregation are also similar in magnitude to each other, and to the segregation point estimates reported in table 2 . These results suggest that the positive and disproportionate relationship between segregation and black low birth weight, compared to that of whites, between 1990 and 2010 is not simply being driven by the scenarios described above. Importantly, these results are not consistent with the association between segregation and black low birth weight being driven exclusively by changes in segregation, nor are they consistent with the association being driven primarily by unobservable trends in high segregation cities. Rather, we find that base levels and recent changes in segregation are equally important in predicting black low birth weight between 1990 and 2010 .

An additional concern is that cities with persistently high black low birth weight experienced increases in segregation over time and it is this increase in segregation that is driving our main results. We can augment equation (2) to rule out this possibility by regressing 1970 and 1980 outcomes on contemporaneous and future changes in segregation. Columns 4 and 5 report results from regressions of 1970 and 1980 outcomes to examine whether future changes in segregation (e.g., 1970-1990, 1970-2000, 1980-1990, or 1980-2000 changes) are correlated with low birth weight in 1970 and 1980. If the 1990-2010 results are being driven by MSAs with high propensities of low birth weight experiencing increases in segregation, then we would expect to find an association between low birth weight in 1970 and 1980 and future changes in segregation. Here, as in table 2, we find no statistically significant association between black low birth weight and 1970 segregation. The coefficients on the interaction terms between segregation changes and our black indicator variable are statistically significant in columns 4 and 5 but negative, suggesting that MSAs experiencing increases in segregation between 1970-1990, 1970- 
2000, and 1970-2010 had lower rates of low birth weight for black residents in 1970. This further supports the notion that the emergence of a positive relationship between segregation and low birth weight is not being driven by changes in segregation across places.

\section{The Potential Role of Selective Migration Across MSAs}

A spurious correlation between segregation and birth outcomes may arise from more educated black parents, who have better infant health on average, differentially moving from high to low segregation MSAs relative to white parents. Using the 5 percent IPUMS samples of the decennial census, we calculate the proportion of young adults that report having recently moved from a high to low, or low to high, segregation MSA in 1980, 1990, and 2000. The sample is limited to observations that reported living in an MSA five years prior to the census date. We focus on young adults (20-30 year olds) as they have the highest birth rates and are most likely to migrate during this period. We exclude 1970 and 2010 as neither the 1970 census nor the 2010 ACS asked respondents to list place of residence five years prior.

Table 6 breaks out migration rates by education level for 20-30 year old black individuals. The likelihood that black young adults move from high to low vs. low to high segregation is similar in all time periods and for high school dropouts, high school graduates, and individuals with some college. The largest differences appear for college graduates, however this group is more likely to move to a more segregated MSA in all years, which works against finding a negative effect of segregation on birth outcomes. ${ }^{12}$

\footnotetext{
${ }^{12}$ Cutler and Glaeser (1997) are able to rerun their main regressions using the segregation level of the city of residence five years prior, because the outcome variable and city of previous residence are drawn from the same census microdata sample. We do not have a record of previous residence in the natality data to run the same test.
} 


\section{Why Does the Relationship Change Over Time?}

Clearly, a deterioration in the health of black infants living in highly segregated cities (relative to less segregated cities) emerged sometime during the 1980s and remains to this day. In this section, we leverage parental characteristics recorded on birth certificates to determine how much of the full effect of segregation can be explained by (or is working through) parental observables, or factors that load onto these characteristics.

Birth certificates record a number of characteristics reported by the mother: marital status, month of first prenatal care, education level and age of mother, and birth order. Many of these characteristics have been shown to either 1) be correlated with and/or have a causal impact on the likelihood of low birth weight, or 2) be correlated with segregation. Black residents in highly segregated MSAs receive lower incomes, have lower education, and are more likely to be single mothers (Cutler and Glaeser 1997). Moreover, behavioral choices during pregnancy such as tobacco, alcohol, or drug use, receipt of prenatal care, nutrition, and environmental factors such as pollution may potentially drive the negative impact of segregation on birth weight (Ellen 2000).

A number of the individual characteristics of the mother vary with segregation in our sample and evolve over the 40-year period under examination. Appendix table A8 reports mean values of each characteristic for low- and high-segregation MSAs (top and bottom quartiles of MSAs ranked by the dissimilarity index). Black mothers residing in highly segregated MSAs are less likely to be married, similar to the finding of Cutler and Glaeser (1997). Moreover, the gap is relatively small in 1970 and increases in the 1970s and 80 s at the same time as the emergence 
of the adverse effect of segregation on black birth outcomes. ${ }^{13}$ The receipt of prenatal care in the first trimester is a proxy for access to maternal health care. In 1970-80, black mothers in highsegregation MSAs were more likely to receive care in the first trimester. However, this gap disappeared by 1990 and turned negative in 2000 and 2010. Finally, while the education levels of black mothers increased steadily, there was no education gap between high- and low-segregated MSAs in 1970. But, by 1980 black mothers in high-segregation MSAs were 4 percentage points less likely to be high school graduates. The gap widened to 5 percentage points in 1990, and fell slightly to 4.5 and 3.4 percentage points in 2000 and 2010.

We formally test how much of the segregation effect can be explained by the fact that segregation causes - or at least is correlated with - movements in parental characteristics known to affect the likelihood of low birth weight. We do this by comparing changes in the estimated year-specific segregation coefficients between specifications with and without the individuallevel parent characteristics discussed above. Again, the sample is limited to births to black mothers to simplify interpretation of the results. ${ }^{14}$ We estimate the following equation at the individual level:

(3) $L B W_{i, t}=\alpha+\beta_{1 t}$ segregation ${ }_{M S A, t}+X_{M S A, t}{ }^{\prime} \theta_{t}^{M S A}+X_{i, t}^{\prime} \theta_{t}^{i}+\delta_{r, t}+\gamma_{t}+\varepsilon_{i, t}$, which allows for year-specific coefficient estimates on segregation. The same time-varying MSA-level controls as in the previous section are included in $X_{M S A, t}$. Individual-level controls,

\footnotetext{
${ }^{13}$ The pattern of increasing correlation of segregation with black single motherhood is also observed in census data (Collins and Margo, 2000).

${ }^{14}$ Running a pooled model with interactions with race does not substantively change the interpretation.
} 
$X_{i, t}$, include an indicator for marital status, a series of indicators for whether the mother graduated from high school, had some college education, and graduated college, an indicator for receipt of prenatal care in the first trimester, the age of the mother, birth order of the child, and an indicator for the sex of the birth. All estimates include year indicators and time-varying region fixed effects. We restrict the sample to observations with full information, which excludes approximately 23 percent of the observations of black births included in our previous analysis. However, the restricted sample for which all information is recorded is not meaningfully different from full sample.

Table 5 reports results from estimation of equation (3). Column (1) contains estimates for the full sample of births to black mothers, for which we see the emergence of the negative impact of segregation shown in the previous section. ${ }^{15}$ The pattern does not meaningfully change when the sample is limited to births for which all parental characteristics are recorded on the birth certificate, as seen in column (2).

Column (3) includes individual-level controls for covariates that have a potential independent effect on low birth weight through segregation causing a compositional change of mothers and allows the coefficients on these covariates to vary across years. Column (4) requires the coefficients to remain constant across years. Figure 3 plots the segregation coefficient estimates for column (2) and column (3). We find that even when controlling for parental characteristics, the estimated coefficients for segregation remain large and statistically significant in 1990, 2000, and 2010. The results in column (2) are consistent with segregation explaining 3135 percent of the black-white gap in low birth weight between 1990 and 2010, assuming no

\footnotetext{
${ }^{15}$ The coefficients on segregation in column 1 are the sums of the coefficients on segregation and the segregation-black interaction term in column 6 of table 2 .
} 
effect of segregation for whites. Comparing columns (2) and (3), we find that the segregation coefficient for 1990-2000 is reduced by 37-44 percent when controls for observable parental characteristics are added. Using the coefficients from column (3) as a lower-bound estimate, we find that segregation continues to explain 18-22 percent of the black-white gap even after controlling for these individual characteristics. The estimates for 1990-2010 do not substantially change when we restrict the coefficients on individual characteristics from varying year to year (column (3) to column (4)). We interpret this as the explanatory power of the parental observables largely coming from segregation-induced differences across MSAs in the composition of mothers as opposed to differences in the effects of the characteristics over time.

We prefer to interpret the base specification without individual controls as the true association, with any changes in the estimate after controlling for individual characteristics due to a mediating effect. In other words, we over-control for factors when including mother-specific characteristics in the regression. However, we cannot rule out that the individual controls are not mediators, and changes in the estimates across specifications are due to omitted variable bias. Importantly, even after adding individual controls, the large and statistically significant impact of segregation on low birth weight remains.

Moving to the early years of the sample, when conditioning on observable parental characteristics, the impact of segregation is negative in both 1970 and 1980 (although the coefficient in 1980 is imprecisely estimated). So, while the overall effect of segregation was nil in these two years, the unexplained portion of the segregation effect actually lowered the likelihood of low birth weight outcomes for black mothers.

Solely looking at how the coefficients on segregation change when adding controls obscures the individual impacts of each covariate. To better explore how each of the covariates 
can explain changes over time, we implement Gelbach's (2016) method, based on the omitted variable bias formula, that allows estimates of the individual impact of a covariate on the coefficient of interest conditional on all other covariates. The procedure takes the estimated coefficients from the specification without parental controls and the specification with parental controls and decomposes the full difference in estimates into the contribution from each added control in the full specification (the difference between column (2) and column (3) of table 5).

We apportion the change in the segregation coefficient from the base to the full specification for each sample year separately. Columns (1) and (2) of table 6 lists the coefficient estimates from the specification without and then with parental controls; these are the same as in table 5. Column (3) reports the full difference between specifications, which can be interpreted as the explained portion of the segregation effect. The remaining columns report the contribution to the difference between specifications that can be allocated to each covariate or group of covariates. Alternatively, the results can be interpreted as the amount in percentage points that a given group of covariates moves the coefficient on segregation conditional on all other covariates. Figure 4 plots the results of the decomposition exercise to easily see the relative contribution of each parental characteristic, and any changes in its contribution over time.

The single largest observable contributor to segregation effect is marital status. In 1970, marital status provided 0.55 percentage points of the segregation effect, followed by 1.14 percentage points in $1980,1.51$ percentage points in $1990,0.87$ percentage points in 2000 , and 1.16 percentage points in 2010 . The sharp increase over the 1970 s in the relationship among marital status, segregation, and low birth is distinct. The fall in importance of marital status come from two parts: a decreasing marriage premium for birthweight (Buckles and Price 2013), and a decreasing difference in marriage rates between high- and low-segregation MSAs. Birth order 
and mother's education come next in importance, but their contributions are roughly a third to half the magnitude of the contribution of marital status.

Surprisingly, receipt of prenatal care shows no importance for the relationship between segregation and low birth weight. We take this as evidence that a differential access to care for black women in highly segregated cities is not an important driver of segregation's negative effects. Thus, the theory of spatial mismatch between black mothers and providers of health care does not seem important. Note that we do not have a measure of the quality of care received by mothers, and cannot rule out that quality differences may be important.

\section{Discussion}

We build on the important work of Ellen (2000) by documenting the emergence of a strong positive correlation between residential racial segregation and low birth weight for births to black mothers in the 1980s. This link is robust to the inclusion of time- and race-specific MSA level controls and a set of region-by-race-by-year fixed effects to account for factors correlated with segregation and a variety of robustness checks.

The main takeaway from our work is that the negative impact of segregation evolves over time, emerging only after 1970 and increasing during the 1980s. Interestingly, this pattern of emergence after 1970 mimics that found for other non-health outcomes such as educational attainment, income, idleness, and single-motherhood (Collins and Margo 2000; Vigdor 2002). Outcomes for African-Americans began to deteriorate in highly segregated cities in the late-70s and 1980s along many dimensions. Further research is required to understand the negative segregation effect on infant health, as well as the many other outcomes. Our research, in 
conjunction with that of others, suggests that researchers look for structural breaks in underlying causes for which outcomes would begin to appear in the 1980 s.

Moreover, the cause of segregation's negative impact on birth outcomes remains an open question, although a number of theories have been developed. Our results suggest that policymakers interested in reducing the large and persistent racial disparities in birth outcomes should explore policies that either reduce residential racial segregation or counteract the negative effects of that segregation on the health of mothers. However, policies to directly reduce segregation itself are costly and ethically difficult (Boustan 2011). The more fruitful path may be to invest in public health initiatives that improve the health behaviors of black mothers, reduce the stressors associated with segregation, and improve the quality of medical care. 


\section{References}

Ananat, Elizabeth Oltmans. 2011. "The Wrong Side(s) of the Tracks: The Causal Effects of Racial Segregation on Urban Poverty and Inequality." American Economic Journal: Applied Economics, 3(2): 34-66.

Barker, D.J.P. 1995. "Fetal Origins of Coronary Heart Disease." British Journal of Medicine 311(6998): 171-174.

Behrman, Jere R., and Mark R. Rosenzweig. "The Returns to Birth Weight," Review of Economics and Statistics, LXXXVI (2004), 586-601.

Bell, Janice F., Frederick J. Zimmerman, Gunnar R. Almgren, Jonathan D. Mayer, Colleen E. Huebner. 2006. "Birth outcomes among urban African-American women: A multilevel analysis of the role of racial residential segregation." Social Science \& Medicine, 63:3030-3045.

Bird ST. 1995. "Separate black and white infant mortality models: differences in the importance of structural variable,". Social Science \& Medicine, 41(11):1507-1512.

Black, Sandra E., Paul J. Devereux, and Kjell G. Salvanes. 2007. "From the Cradle to the Labor Market? The Effect of Birth Weight on Adult Outcomes." The Quarterly Journal of Economics.

Boustan, Leah Platt. 2011. "Racial Residential Segregation in American Cities." in Handbook of Urban Economics and Planning, eds. Nancy Brooks, Kieran Donaghy and Gerrit Knaap. Oxford University Press.

Britton, Marcus L. and Heeju Shin. 2013. "Metropolitan residential segregation and very preterm birth among African American and Mexican-origin women." Social Science \& Medicine, 98:37-45.

Buckles, Kasey S. and Joseph Price. 2013. "Selection and the Marriage Premium for Infant Health.” Demography 50: 1315-1339.

Case, Anne and Christina Paxson. 2010. "Causes and Consequences of Early-Life Health." Demography 47(S): S65-S85.

Catalano, R., and Hartig, T. (2001). "Communal bereavement and the incidence of very low birthweight in Sweden." Journal of Health and Social Behavior 42: 333-34.

Collins, J., R. David, R. Symons, A. Handler, S. Wall, and L. Dywer. (2000). "Low-income African-American mothers' perception of exposure to racial discrimination and infant birth weight." Epidemiology 11: 337-339.

Collins, William and Robert Margo. 2000. "Residential segregation and socioeconomic outcomes: When did ghettos go bad," Economics Letters, Elsevier, vol. 69(2), pages 239243, November.

Conley, Dalton and Neil G. Bennett. 2001. "Birth Weight and Income: Interactions across Generations." Journal of Health and Social Behavior 42(4): 450-465.

Curhan, Gary C., Walter C. Willett, Eric B. Rimm, Donna Spiegelman, Alberto Ascherio, and Meir J. Stampfer. 1996. "Birth Weight and Adult Hypertension, Diabetes Mellitus, and Obesity in US Men." Circulation 94: 3246-3250.

Currie, Janet and Enrico Moretti. 2003. "Mother's Education and the Intergenerational Transmission of Human Capital: Evidence from College Openings, The Quarterly Journal of Economics, 118(4):1495-1532.

Currie, Janet and Enrico Moretti. 2007. "Biology as Destiny? Short and Long-Run Determinants of Intergenerational Transmission of Birth Weight." The Journal of Labor Economics 
25(2): 231-264

Currie, Janet, Matthew Neidell, and Johannes F. Schmieder. 2009. "Air pollution and infant health: Lessons from New Jersey.” Journal of Health Economics, 28(3):688-703.

Currie, Janet, and Johannes F. Schmieder. 2009. "Fetal Exposures to Toxic Releases and Infant Health." The American Economic Review, 99(2)):177-183.

Currie, Janet, and Reed Walker. 2011. "Traffic Congestion and Infant Health: Evidence from EZPass." American Economic Journal: Applied Economics, 3(1): 65-90.

Cutler, David M. and Edward L. Glaeser. 1997. "Are Ghettos Good or Bad?" Quarterly Journal of Economics 112: 827-872.

Debbink, Michelle P., Michael D. M. Bader. 2011. "Racial Residential Segregation and Low Birth Weight in Michigan's Metropolitan Areas." American Journal of Public Health 101(9):1714-1720.

Ellen, Ingrid Gould. 2000. "Is Segregation Bad for Your Health? The Case of Low Birth Weight." Brookings-Wharton Papers on Urban Affairs: 203-238.

Evans, William N. and Jeanne S. Ringel. 1999. "Can higher cigarette taxes improve birth outcomes?” Journal of Public Economics, 72(1):135-154.

Fertig, Angela and Tara Watson. 2009. "Minimum Drinking Laws and Infant Health Outcomes." Journal of Health Economics, 28(3):737-47.

Figlio, David, Jonathan Guryan, Krzysztof Karbownik, and Jeffrey Roth. 2014. "The Effects of Poor Neonatal Health on Children's Cognitive Development." American Economic Review, 104(12): 3921-55.

Gelbach, Jonah B. 2016. "When Do Covariates Matter? And Which Ones, and How Much?, Journal of Labor Economics 34(2): 509-543.

Grady, Sue C. 2006. "Racial disparities in low birthweight and the contribution of residential segregation: A multilevel analysis," Social Science \& Medicine, 63: 3013-3029.

Grady, Sue C. 2010. "Racial residential segregation impacts on low birth weight using improved neighborhood boundary definitions." Spatial and Spatiotemporal Epidemiology, 1(4):239-249.

Guest, Avery M, Gunnar Almgren, and Jon M. Hussey. 1998. "The Ecology of Race and Socioeconomic Distress: Infant and Working-Age Mortality in Chicago." Demography, 35(1):23-24.

Hoffman, Susie and Maureen C. Hatch. 1996. "Stress, social support and pregnancy outcome: a reassessment based on recent research." Pediatric and Perinatal Epidemiology, 10(4):380-405

Hearst, Mary O., J. Michael Oakes, and Pamela Jo Johnson. 2008. "The Effect of Racial Residential Segregation on Black Infant Mortality." American Journal of Epidemiology, 168(11):1247-1254.

Hoynes, Hilary, Marianne Page, and Ann Huff Stevens. 2011. "Can targeted transfers improve birth outcomes? Evidence form the introduction of the WIC program." Journal of Public Economics, 95:813-827.

Jacobson, Joseph L., Sandra W. Jacobson, Robert J. Sokol, Susan S. Martier, Joel W. Ager, and Seetha Shankaran. 1994. "Effects of alcohol use, smoking, and illicit drug use on fetal growth in black infants." The Journal of Pediatrics 124(5): 757-764.

Kramer, Michael R. and Carol R. Hogue. 2008. "Place Matters: Variation in the Black/White Very Preterm Birth Rate across U.S. Metropolitan Areas, 2002-2004.” Women's and 
Children's Center, Department of Epidemiology, Rollins School of Public Health, Emory University, 123(5):576-585.

Kramer, Michael R., Hannah L. Cooper, Carolyn D. Drews-Botsch, Lance A. Waller, and Carol R. Hogue. 2010. "Metropolitan isolation segregation and Black-White disparities in very preterm birth: A test of mediating pathways and variance explained." Social Science \& Medicine, 71(12):2108-2116.

Lauderdale, D. S. 2006. "Birth outcomes for Arabic-named women in California before and after September 11." Demography 43:185-201.

Laveist TA.. 1993. "Segregation, poverty, and empowerment: health consequences for African Americans," Milbank Quarterly, 71(1):41-64.

Lhila, Aparna, and Sharon Long. 2011. "What is driving the black-white difference in low birthweight in the U.S.?" Health Economics 21:301-315.

Martin, Joyce A., Brady E. Hamilton, Stephanie J. Ventura, Fay Menacker, and Melissa M. Park., "Births: Final Data for 2000," National Vital Statistics Reports 52, no. 10 (Hyattsville, Md.: National Center for Health Statistics, February 12, 2002).

Massey, Douglas S. and Nancy A. Denton. 1988. "The Dimensions of Residential Segregation." Social Forces, 67(2): 281-315.

Massey, Douglas S. and Nancy A. Denton. 1993. American Apartheid: Segregation and the Making of the Underclass. Harvard University Press.

Mathews, T. J. and B. E. Hamilton. (2018). "Total fertility rates by state and race and Hispanic origin: United States, 2017." National Vital Statistics Reports 68(1). Hyattsville, MD: National Center for Health Statistics.

Moiduddin, Emily and Douglas S. Massey. 2008. "Neighborhood Disadvantage and Birth Weight: The Role of Perceived Danger and Substance Abuse." International Journal of Conflict and Violence, 2(1):113-129.

National Center for Health Statistics (NCHS) Data File Documentations, Natality, 1970, 1971, 1980, 1981, 1990, 1991 (machine readable data file and documentation, CD-ROM Series), National Center for Health Statistics, Hyattsville, Maryland.

Noonan, Kelly, Nancy E. Reichman, Hope Corman, and Dhaval Dave. 2007. "Prenatal drug use and the production of infant health." Health Economics, 16(4):361-84.

Oreopoulos, Philip, Mark Stabile, Randy Walld, and Leslie Roos. 2008. "Short, Medium, and Long Term Consequences of Poor Infant Health: An Analysis using Siblings and Twins." Journal of Human Resources 43(1): 88-138.

Osypuk TL, Acevedo-Garcia D.. 2008. "Are racial disparities in preterm birth larger in hypersegregated areas?" American Journal of Epidemiology. 167(11):1295-1304.

Pickett, Kate E., James W. Collins, Christopher M. Masi, and Richard G. Williamson. 2005. "The effects of racial density and income incongruity on pregnancy outcomes," Social Science \& Medicine, 60: 2229-2238.

Polednak AP. 1991. "Black-white differences in infant mortality in 38 standard metropolitan statistical areas," American Journal of Public Health, 81(11):1480-1482.

Polednak AP. 1996. "Trends in US urban black infant mortality, by degree of residential segregation," American Journal of Public Health, 86(5):723-726.

Roberts, Eric M. 1997. "Neighborhood Social Environments and the Distribution of Low Birthweight in Chicago," American Journal of Public Health, 87(4): 597-603.

Royer, Heather. 2009. "Separated at Girth: US Twin Estimates of the Effects of Birth Weight." American Economic Journal: Applied Economics, 1(1): 49-85. 
Ruggles, Steven, Katie Genadek, Ronald Goeken, Josiah Grover, and Matthew Sobek. Integrated Public Use Microdata Series: Version 7.0 (1980, 1990, 2000). Minneapolis: University of Minnesota, 2018.

Shertzer, Allison, Tate Twinam, and Randall P. Walsh. 2016. "Race, Ethnicity, and Discriminatory Zoning." American Economic Journal: Applied Economics, 8(3): 217-46. Torche, Florencia. 2011. "The Effect of Maternal Stress on Birth Outcomes: Exploiting a Natural Experiment." Demography 48: 1473-1491.

United States Bureau of the Census. 1972. "1970 Census of Population: General Social and Economic Characteristics: United States Summary." Washington: US GPO.

United States Bureau of the Census. 1984. "1980 Census of Population: General Social and Economic Characteristics: United States Summary.” Washington: US GPO.

U.S. Census Bureau. 1970, 1980, 1990, 2000. Prepared by Social Explorer. (accessed May 2016)

Vigdor, Jacob L. 2002. "Locations, Outcomes, and Selective Migration." The Review of Economics and Statistics, 84(4): 751-755.

Williams, DR and C. Collins. 2001. "Racial residential segregation: a fundamental cause of racial disparities in health." Public Health Reports 116(5): 404-16. 
Table 1: Summary statistics likelihood of low birth rate across MSAs by year, race, and level of segregation

\begin{tabular}{|c|c|c|c|c|c|c|c|c|c|c|}
\hline \multirow{3}{*}{ Low Birth Weight: $\%<2,50$} & \multicolumn{2}{|c|}{1970} & \multicolumn{2}{|c|}{$\underline{1980}$} & \multicolumn{2}{|c|}{$\underline{1990}$} & \multicolumn{2}{|c|}{$\underline{2000}$} & \multicolumn{2}{|c|}{$\underline{2010}$} \\
\hline & Black & White & Black & White & Black & White & Black & White & Black & White \\
\hline & \multicolumn{10}{|c|}{ Low Birth Weight: $\%<2,500$ grams } \\
\hline All & 0.1392 & 0.0674 & 0.1286 & 0.0572 & 0.1359 & 0.0560 & 0.1300 & 0.0647 & 0.1316 & 0.0688 \\
\hline$N$ & 810,854 & $3,579,688$ & 907,474 & $3,851,740$ & $1,122,757$ & $4,330,310$ & $1,033,895$ & $4,329,128$ & $1,051,346$ & $4,023,902$ \\
\hline Bottom $10 \%$ Segregation & 0.1465 & 0.0690 & 0.1165 & 0.0560 & 0.1150 & 0.0522 & 0.1249 & 0.0630 & 0.1188 & 0.0646 \\
\hline$N$ & 17,898 & 148,482 & 25,470 & 207,337 & 21,917 & 279,860 & 22,910 & 396,509 & 18,560 & 301,621 \\
\hline Top $10 \%$ Segregation & 0.1399 & 0.0660 & 0.1351 & 0.0567 & 0.1454 & 0.0559 & 0.1352 & 0.0662 & 0.1344 & 0.0694 \\
\hline$N$ & 219,134 & 875,352 & 220,121 & 722,694 & 282,391 & 768,501 & 227,750 & 713,525 & 283,385 & 720,136 \\
\hline $\begin{array}{l}\text { Difference } \\
\text { (Top - Bottom Deciles) }\end{array}$ & -0.0066 & -0.0030 & 0.0186 & 0.0007 & 0.0304 & 0.0037 & 0.0103 & 0.0032 & 0.0156 & 0.0048 \\
\hline & \multicolumn{2}{|c|}{1970} & \multicolumn{2}{|c|}{1980} & \multicolumn{2}{|c|}{1990} & \multicolumn{2}{|c|}{2000} & \multicolumn{2}{|c|}{2010} \\
\hline \multicolumn{3}{|l|}{$\underline{\text { Dissimilarity Index }}$} & \multirow{2}{*}{\multicolumn{2}{|c|}{$\begin{array}{c}0.6335 \\
(0.1234)\end{array}$}} & \multirow{2}{*}{\multicolumn{2}{|c|}{$\begin{array}{c}0.5736 \\
(0.1283)\end{array}$}} & \multirow{2}{*}{\multicolumn{2}{|c|}{$\begin{array}{c}0.5260 \\
(0.1257)\end{array}$}} & \multirow{2}{*}{\multicolumn{2}{|c|}{$\begin{array}{c}0.4766 \\
(0.1176)\end{array}$}} \\
\hline$\overline{\text { Mean }}$ & $\begin{array}{l}0 . \\
(0 .\end{array}$ & $\begin{array}{l}264 \\
106)\end{array}$ & & & & & & & & \\
\hline \multicolumn{11}{|l|}{$\begin{array}{l}\text { Distribution } \\
\text { (Percentiles) }\end{array}$} \\
\hline $90^{\text {th }}$ & \multicolumn{2}{|c|}{0.8583} & \multicolumn{2}{|c|}{0.7720} & \multicolumn{2}{|c|}{0.7286} & \multicolumn{2}{|c|}{0.6871} & \multicolumn{2}{|c|}{0.6314} \\
\hline $75^{\text {th }}$ & \multicolumn{2}{|c|}{0.8057} & \multicolumn{2}{|c|}{0.7249} & \multicolumn{2}{|c|}{0.6703} & \multicolumn{2}{|c|}{0.6110} & \multicolumn{2}{|c|}{0.5556} \\
\hline $50^{t h}$ & \multicolumn{2}{|c|}{0.7499} & \multicolumn{2}{|c|}{0.6588} & \multicolumn{2}{|c|}{0.5928} & \multicolumn{2}{|c|}{0.5355} & \multicolumn{2}{|c|}{0.4741} \\
\hline $25^{\text {th }}$ & \multicolumn{2}{|c|}{0.6578} & & 423 & 0.4 & 965 & 0.4 & & 0.3 & 66 \\
\hline $10^{t h}$ & & 5662 & & 619 & 0.3 & 962 & 0.3 & & 0.3 & 24 \\
\hline Observations & & 75 & & 20 & 2 & 7 & & & & \\
\hline
\end{tabular}

Notes: The reported summary statistics on low birth weight were constructed using individual-level data from children born to white and black mothers. We pool birth data from two years for each decade (e.g., 1970 and 1971, 1980 and 1981, etc.). Segregation summary statistics were constructed using an unweighted sample of MSAs in our sample. Individual birth weight data comes from the National Center for Health Statistics Natality Detail File 1970-2011. Segregation statistics were created using tract-level Census data from Social Explorer (2016). 
Table 2: Segregation and Low Birth Weight, 1970-2010

\begin{tabular}{|c|c|c|c|c|c|c|c|}
\hline & \multicolumn{5}{|c|}{ Full Sample } & \multicolumn{2}{|c|}{ Consistent Sample } \\
\hline & (1) & (2) & (3) & (4) & (5) & $(6)$ & (7) \\
\hline \multirow[t]{2}{*}{ Segregation x Black x 2010} & $0.0158 * *$ & $0.0295^{* * *}$ & $0.0321 * *$ & $0.0438^{* * *}$ & $0.0474 * * *$ & $0.0395^{* * *}$ & $0.0448 * * *$ \\
\hline & $(0.0076)$ & $(0.0089)$ & $(0.0110)$ & $(0.0116)$ & $(0.0082)$ & $(0.0141)$ & $(0.0097)$ \\
\hline \multirow[t]{2}{*}{ Segregation x Black x 2000} & 0.0160 & $0.0240 * * *$ & $0.0230 * *$ & $0.0328 * * *$ & $0.0337 * * *$ & $0.0316^{* *}$ & $0.0345^{* * *}$ \\
\hline & $(0.0098)$ & $(0.0086)$ & $(0.0115)$ & $(0.0124)$ & $(0.0098)$ & $(0.0155)$ & $(0.0120)$ \\
\hline \multirow[t]{2}{*}{ Segregation x Black x 1990} & $0.0557 * * *$ & $0.0437 * * *$ & $0.0571 * * *$ & $0.0371 * * *$ & $0.0363 * * *$ & $0.0370 * * *$ & $0.0353 * * *$ \\
\hline & $(0.0072)$ & $(0.0071)$ & $(0.0097)$ & $(0.0100)$ & $(0.0089)$ & $(0.0132)$ & $(0.0112)$ \\
\hline \multirow[t]{2}{*}{ Segregation x Black x 1980} & $0.0343 * * *$ & $0.0280 * * *$ & $0.0233 * * *$ & 0.0182 & $0.0190^{*}$ & 0.0083 & 0.0071 \\
\hline & $(0.0107)$ & $(0.0103)$ & $(0.0086)$ & $(0.0123)$ & $(0.0111)$ & $(0.0154)$ & $(0.0137)$ \\
\hline \multirow[t]{2}{*}{ Segregation x Black x 1970} & 0.0113 & -0.0029 & 0.0112 & 0.0127 & 0.0150 & 0.0102 & 0.0109 \\
\hline & $(0.0108)$ & $(0.0110)$ & $(0.0107)$ & $(0.0134)$ & $(0.0118)$ & $(0.0134)$ & $(0.0117)$ \\
\hline \multirow[t]{2}{*}{ Segregation x 2010} & $0.0116^{* * *}$ & $0.0153 * * *$ & 0.0047 & $0.0174 *$ & 0.0022 & $0.0195^{*}$ & 0.0036 \\
\hline & $(0.0044)$ & $(0.0048)$ & $(0.0069)$ & $(0.0093)$ & $(0.0053)$ & $(0.0114)$ & $(0.0058)$ \\
\hline \multirow[t]{2}{*}{ Segregation x 2000} & $0.0085 * *$ & $0.0139 * * *$ & 0.0005 & 0.0130 & 0.0028 & 0.0124 & 0.0016 \\
\hline & $(0.0041)$ & $(0.0041)$ & $(0.0069)$ & $(0.0091)$ & $(0.0046)$ & $(0.0121)$ & $(0.0052)$ \\
\hline \multirow[t]{2}{*}{ Segregation x 1990} & 0.0015 & 0.0039 & -0.0020 & 0.0049 & -0.0025 & 0.0084 & 0.0010 \\
\hline & $(0.0040)$ & $(0.0031)$ & $(0.0056)$ & $(0.0065)$ & $(0.0040)$ & $(0.0089)$ & $(0.0049)$ \\
\hline \multirow[t]{2}{*}{ Segregation x 1980} & 0.0005 & 0.0036 & -0.0003 & 0.0014 & -0.0023 & -0.0003 & -0.0017 \\
\hline & $(0.0044)$ & $(0.0040)$ & $(0.0048)$ & $(0.0069)$ & $(0.0046)$ & $(0.0081)$ & $(0.0055)$ \\
\hline \multirow[t]{2}{*}{ Segregation x 1970} & -0.0056 & -0.0053 & -0.0012 & 0.0007 & -0.0001 & 0.0012 & 0.0023 \\
\hline & $(0.0072)$ & $(0.0088)$ & $(0.0071)$ & $(0.0087)$ & $(0.0051)$ & $(0.0088)$ & $(0.0052)$ \\
\hline MSA-Year Controls & No & Yes & No & Yes & Yes & Yes & Yes \\
\hline Region x Year Fixed Effects & No & No & Yes & Yes & Yes & Yes & Yes \\
\hline MSA Fixed Effects & No & No & No & No & Yes & No & Yes \\
\hline Observations & $25,041,094$ & $25,041,094$ & $25,041,094$ & $25,041,094$ & $25,041,094$ & $20,884,335$ & $20,884,335$ \\
\hline
\end{tabular}


Table 3: Segregation and Low Birth Weight: Base Levels of Segregation and Changes over Time

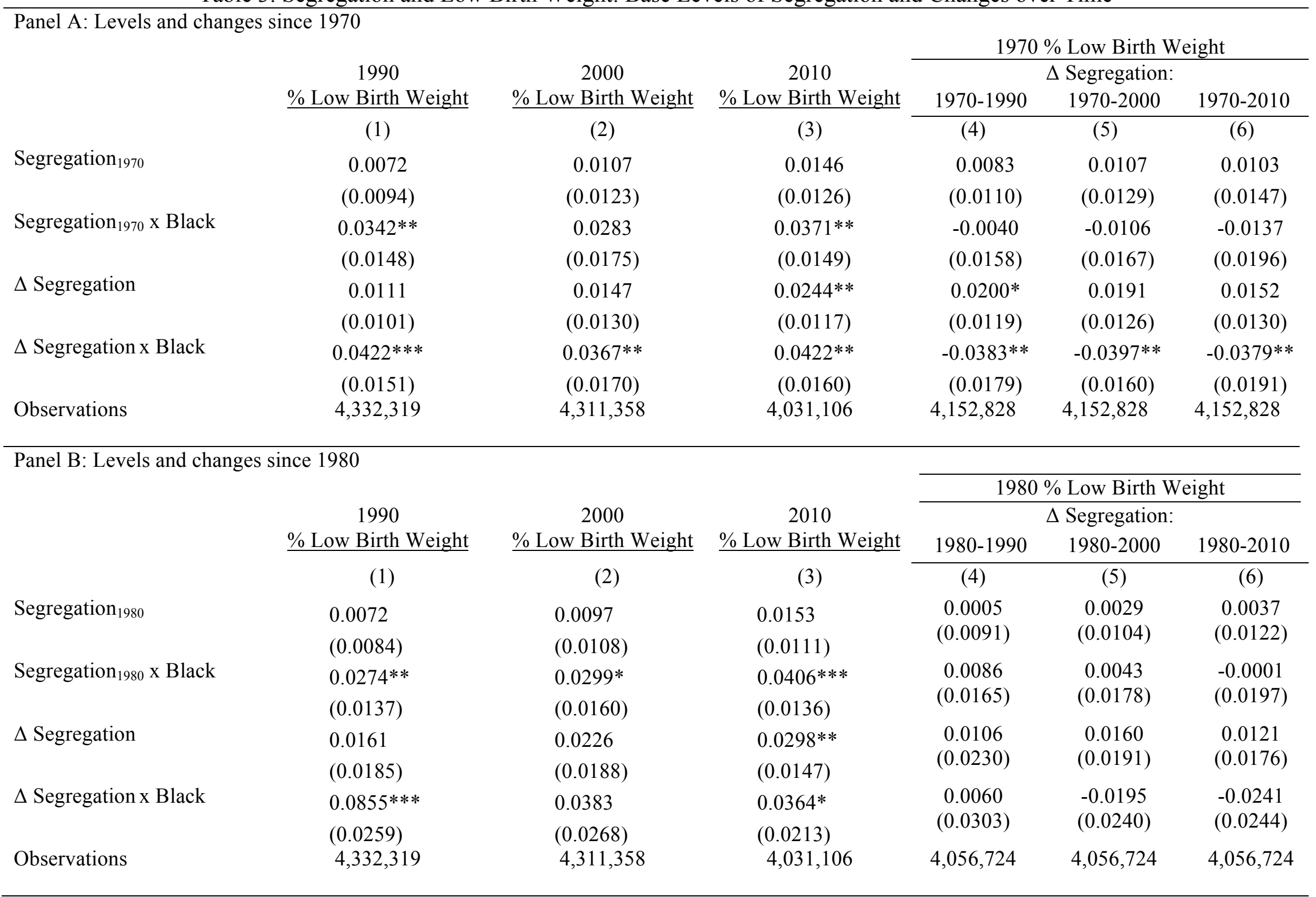


Notes: $* * * \mathrm{p}<0.01, * * \mathrm{p}<0.05, * \mathrm{p}<0.1$. Standard errors adjusted for clustering at the MSA x YEAR level are in parentheses. MSA x Year controls and Region $\mathrm{x}$ Year fixed effects are interacted with our Black indicator variable. MSA controls include log population, percent black, average family income, and percent manufacturing. Individual birth weight data comes from the National Center for Health Statistics Natality Detail File 1970-2011. Segregation and MSA controls were created using tract-level Census data from Social Explorer (2016). 
Table 4: Sorting across metro areas by education level for 20-30-year-old black residents (proportion)

\begin{tabular}{lcccc}
\hline & $\begin{array}{c}\text { High school } \\
\text { dropout }\end{array}$ & $\begin{array}{c}\text { High school } \\
\text { grad }\end{array}$ & $\begin{array}{c}\text { Some } \\
\text { college }\end{array}$ & College grad \\
\cline { 2 - 4 } 1980 & & & & \\
Move to more segregated city & 0.05 & 0.07 & 0.09 & 0.16 \\
Move to less segregated city & 0.04 & 0.07 & 0.09 & 0.12 \\
Move to rural & 0.04 & 0.03 & 0.04 & 0.04 \\
Did not move & 0.86 & 0.83 & 0.78 & 0.68 \\
1990 & & & & \\
Move to more segregated city & 0.06 & 0.07 & 0.10 & 0.16 \\
Move to less segregated city & 0.05 & 0.07 & 0.10 & 0.13 \\
Move to rural & 0.06 & 0.04 & 0.05 & 0.03 \\
Did not move & 0.84 & 0.82 & 0.76 & 0.68 \\
2000 & & & & \\
Move to more segregated city & 0.04 & 0.05 & 0.08 & 0.16 \\
Move to less segregated city & 0.04 & 0.06 & 0.10 & 0.13 \\
Move to rural & 0.06 & 0.03 & 0.04 & 0.03 \\
Did not move & 0.86 & 0.86 & 0.78 & 0.68 \\
1990-1980 & & & & \\
Move to more segregated city & 0.00 & 0.00 & 0.01 & -0.01 \\
Move to less segregated city & 0.00 & 0.00 & 0.01 & 0.01 \\
Move to rural & 0.02 & 0.01 & 0.01 & -0.01 \\
Did not move & -0.03 & -0.01 & -0.02 & 0.00 \\
2000-1980 & & & & \\
Move to more segregated city & -0.02 & -0.02 & -0.01 & 0.00 \\
Move to less segregated city & 0.00 & 0.00 & 0.01 & 0.01 \\
Move to rural & 0.02 & 0.00 & 0.00 & -0.02 \\
Did not move & 0.00 & 0.03 & 0.00 & 0.01 \\
\hline
\end{tabular}

Notes: The sample consists of black and white men and women between 20 and 30 years old living in a metro area five years prior to the census data. IPUMS 5\% samples 1980, 1990 2000. Segregation measures were created using tract-level Census data from Social Explorer (2016). 
Table 5: Total explanatory power of maternal characteristics as channels for the segregation effect

\section{Full Sample}

(1)

Segregation

2010

2000

1990

1980

1970

0.0113

$(0.0119)$

4,562,329

no

Restricted Sample

Individual Controls

Time-varying coeff. on

indiv. controls

$0.0590^{* * *}$

$0.0440^{* * *}$

$0.0454 * * *$

$$
0.0080
$$

no
Restricted Sample

(2)

(3)

(4)

$0.0406^{* * *}$

(0.0151)

0.0238

0.0233

(0.0169)

$(0.0163)$

$0.0435^{* * *}$

$0.0273^{*}$

$0.0258^{*}$

(0.0148)

(0.0150)

(0.0147)

$0.0479 * * *$

$0.0267^{*}$

$0.0292 * *$

(0.0120)

(0.0152)

$(0.0135)$

0.0040

$-0.0164$

$-0.0133$

(0.0146)

(0.0135)

(0.0139)

$-0.0177$

$-0.0307 * *$

$-0.0344^{* *}$

(0.0149)

(0.0148)

(0.0159)
3,528,141
yes
no

$3,528,141$

yes

yes

$3,528,141$
yes
yes

yes

Notes: $* * * \mathrm{p}<0.01,{ }^{* *} \mathrm{p}<0.05, * \mathrm{p}<0.1$. Standard errors adjusted for clustering at the MSA $\mathrm{x}$ YEAR level are in parentheses. The restricted sample includes all births for which there is full information reported on the birth certificate. Each regression includes as controls with time-varying coefficients: year indicators, region indicators, log of MSA population, percent of MSA population that is black, log of MSA average family income, and the percent of MSA employment in manufacturing. Observations are births to black women in the restricted sample for which the dependent variable is reported on the birth certificate. Columns (1) and (2) do not include any individual-level controls. Columns (3) and (4) include controls for mother's marital status, education, and age, an indicator for receipt of prenatal care in the first trimester, birth order, and an indicator for sex of the birth. Individual birth weight data comes from the National Center for Health Statistics Natality Detail File 1970-2011. Segregation and MSA controls were created using tract-level Census data from Social Explorer (2016). 
Table 6: Contribution of individual-level covariates as potential pathways of the segregation effect on low birth weight

\begin{tabular}{|c|c|c|c|c|c|c|c|c|c|}
\hline \multicolumn{4}{|c|}{ Coefficient on segregation } & \multicolumn{6}{|c|}{ Contribution of covariate to difference of base and full specification } \\
\hline & Base & Full & Difference & $\begin{array}{c}\text { Marital } \\
\text { Status }\end{array}$ & $\begin{array}{c}\text { Prenatal } \\
\text { Care }\end{array}$ & $\begin{array}{l}\text { Mother's } \\
\text { Education }\end{array}$ & $\begin{array}{l}\text { Age of } \\
\text { Mother }\end{array}$ & Birth Order & Male \\
\hline 2010 & $\begin{array}{c}0.0406 * * * \\
(0.0151)\end{array}$ & $\begin{array}{c}0.0238 \\
(0.0169)\end{array}$ & $\begin{array}{c}0.0169 * * * \\
(0.0040)\end{array}$ & $\begin{array}{c}0.0116 * * * \\
(0.0027)\end{array}$ & $\begin{array}{c}0.0011 \\
(0.0007)\end{array}$ & $\begin{array}{c}0.0044 * * * \\
(0.0013)\end{array}$ & $\begin{array}{l}-0.0026 \\
(0.0015)\end{array}$ & $\begin{array}{c}0.0025 \\
(0.0027)\end{array}$ & $\begin{array}{l}-0.00004 \\
(0.0002)\end{array}$ \\
\hline 2000 & $\begin{array}{c}0.0435 * * * \\
(0.0148)\end{array}$ & $\begin{array}{l}0.0273 * \\
(0.0150)\end{array}$ & $\begin{array}{c}0.0163 * * * \\
(0.0033)\end{array}$ & $\begin{array}{c}0.0087^{* * *} \\
(0.0020)\end{array}$ & $\begin{array}{c}0.0006 \\
(0.0004)\end{array}$ & $\begin{array}{c}0.0042 * * * \\
(0.0011)\end{array}$ & $\begin{array}{l}-0.0011 \\
(0.0014)\end{array}$ & $\begin{array}{c}0.0039 * * * \\
(0.0014)\end{array}$ & $\begin{array}{l}-0.0001 \\
(0.0002)\end{array}$ \\
\hline 1990 & $\begin{array}{c}0.0479 * * * \\
(0.0120)\end{array}$ & $\begin{array}{l}0.0267^{*} \\
(0.0152)\end{array}$ & $\begin{array}{c}0.0212 * * * \\
(0.0071)\end{array}$ & $\begin{array}{c}0.0151 * * * \\
(0.0032)\end{array}$ & $\begin{array}{l}-0.0026 * \\
(0.0014)\end{array}$ & $\begin{array}{c}0.0055^{* * *} \\
(0.0017)\end{array}$ & $\begin{array}{l}-0.0010 \\
(0.0018)\end{array}$ & $\begin{array}{c}0.0046 \\
(0.0028)\end{array}$ & $\begin{array}{c}-0.0004 * * \\
(0.0002)\end{array}$ \\
\hline 1980 & $\begin{array}{c}0.0040 \\
(0.0146)\end{array}$ & $\begin{array}{l}-0.0164 \\
(0.0135)\end{array}$ & $\begin{array}{c}0.0205 * * * \\
(0.0061)\end{array}$ & $\begin{array}{c}0.0114 * * * \\
(0.0034)\end{array}$ & $\begin{array}{l}-0.0010 \\
(0.0009)\end{array}$ & $\begin{array}{c}0.0036 \\
(0.0023)\end{array}$ & $\begin{array}{c}0.0004 \\
(0.0004)\end{array}$ & $\begin{array}{c}0.0061 * * * \\
(0.0013)\end{array}$ & $\begin{array}{l}-0.0001 \\
(0.0002)\end{array}$ \\
\hline 1970 & $\begin{array}{l}-0.0177 \\
(0.0149)\end{array}$ & $\begin{array}{c}-0.0307 * * \\
(0.0148)\end{array}$ & $\begin{array}{c}0.0130 * * * \\
(0.0038)\end{array}$ & $\begin{array}{c}0.0055 * * * \\
(0.0017)\end{array}$ & $\begin{array}{c}0.0007 \\
(0.0012)\end{array}$ & $\begin{array}{c}0.0029 \\
(0.0018)\end{array}$ & $\begin{array}{c}0.0030 * * \\
(0.0013)\end{array}$ & $\begin{array}{c}0.0022 * * * \\
(0.0007)\end{array}$ & $\begin{array}{c}-0.0013 * * * \\
(0.0005)\end{array}$ \\
\hline $\begin{array}{l}\text { Notes: } \\
\text { depend } \\
\text { segrega } \\
\text { include } \\
\text { in mant } \\
\text { any ind } \\
\text { estimat } \\
\text { differer } \\
\text { segrega } \\
\text { estimat } \\
\text { associa } \\
\text { Detail }\end{array}$ & $\begin{array}{l}* \mathrm{p}<0.01, * \\
t \text { variable is } \\
n \text { index val } \\
\mathrm{s} \text { controls v } \\
\text { cturing, an } \\
\text { dual level c } \\
\text { each year } \\
\text { in terms of } \\
\text { n and low } \\
\text { f the segreg } \\
n \text { of segreg } \\
\text { 1970-201 }\end{array}$ & $\begin{array}{l}0<0.05,{ }^{*} \mathrm{p} \\
\text { ported on } \\
\text { of } 0 \text { to } 1 . \\
\text { h time-var } \\
\text { he natural } \\
\text { atrols. Coll } \\
\text { parately. T } \\
\text { p. betwee } \\
\text { th weight. } \\
\text { ion effect } \\
\text { on and lou } \\
\text { Segregatic }\end{array}$ & $\begin{array}{l}\text { 1. Observa } \\
\text { birth certif } \\
\text { ndard error } \\
\text { g coefficien } \\
\text { of median } \\
\text { (2) reports } \\
\text { remaining o } \\
\text { e base and } \\
\text { e remaining } \\
\text { low birth w } \\
\text { rth weight. } \\
\text { nd MSA co }\end{array}$ & $\begin{array}{l}\text { are of birth } \\
\text { Coefficient } \\
\text { sted for clu } \\
\text { ar effects, r } \\
\text { income. C } \\
\text { ficients for } \\
\text { ns come fro } \\
\text { ll specifica } \\
\text { mns represe } \\
\text { For examp } \\
\text { idual birth } \\
\text { s were creat }\end{array}$ & $\begin{array}{l}\text { black nor } \\
\text { the first } \\
\text { ring at the } \\
\text { on indicat } \\
\text { amn (1) is } \\
\text { full speci } \\
\text { the accour } \\
\text {, which } \mathrm{t} \\
\text { the contrit } \\
\text { marital st } \\
\text { ght data c } \\
\text { using trac }\end{array}$ & $\begin{array}{l}\text { spanic wom } \\
\text { columns ar } \\
\text { A x YEAR } \\
\text { log of popt } \\
\text { base specifi } \\
\text { tion, which } \\
\text { g exercise fi } \\
\text { terpret as th } \\
\text { on of each g } \\
\text { in } 1990 \text { cor } \\
\text { s from the I } \\
\text { vel Census }\end{array}$ & $\begin{array}{l}\mathrm{n} \text { the restr } \\
\text { terpreted a } \\
\text { el are in } \mathrm{p} \\
\text { on, perce } \\
\text { ion from e } \\
\text { ludes all ir } \\
\text { Gelbach } \\
\text { xplained p } \\
\text { p of paren } \\
\text { utes } 1.51 \\
\text { onal Cent } \\
\text { from Soc }\end{array}$ & $\begin{array}{l}\text { d sample fo } \\
\text { he difference } \\
\text { ntheses. Eac } \\
\text { lack, percen } \\
\text { nating equat } \\
\text { jidual-level } \\
\text { 16). Column } \\
\text { ion of the as } \\
\text { characteristi } \\
\text { of the base } \\
\text { or Health } \mathrm{St} \\
\text { Explorer ( } 20\end{array}$ & $\begin{array}{l}\text { which the } \\
\text { noving from a } \\
\text { regression } \\
\text { f employment } \\
\text { n (3) without } \\
\text { ntrols and } \\
3 \text { ) is the } \\
\text { ciation of } \\
\text { to the base } \\
79 \text { p.p. } \\
\text { istics Natality } \\
6) \text {. }\end{array}$ \\
\hline
\end{tabular}


Figure 1: Percent low birth weight and segregation, by MSA
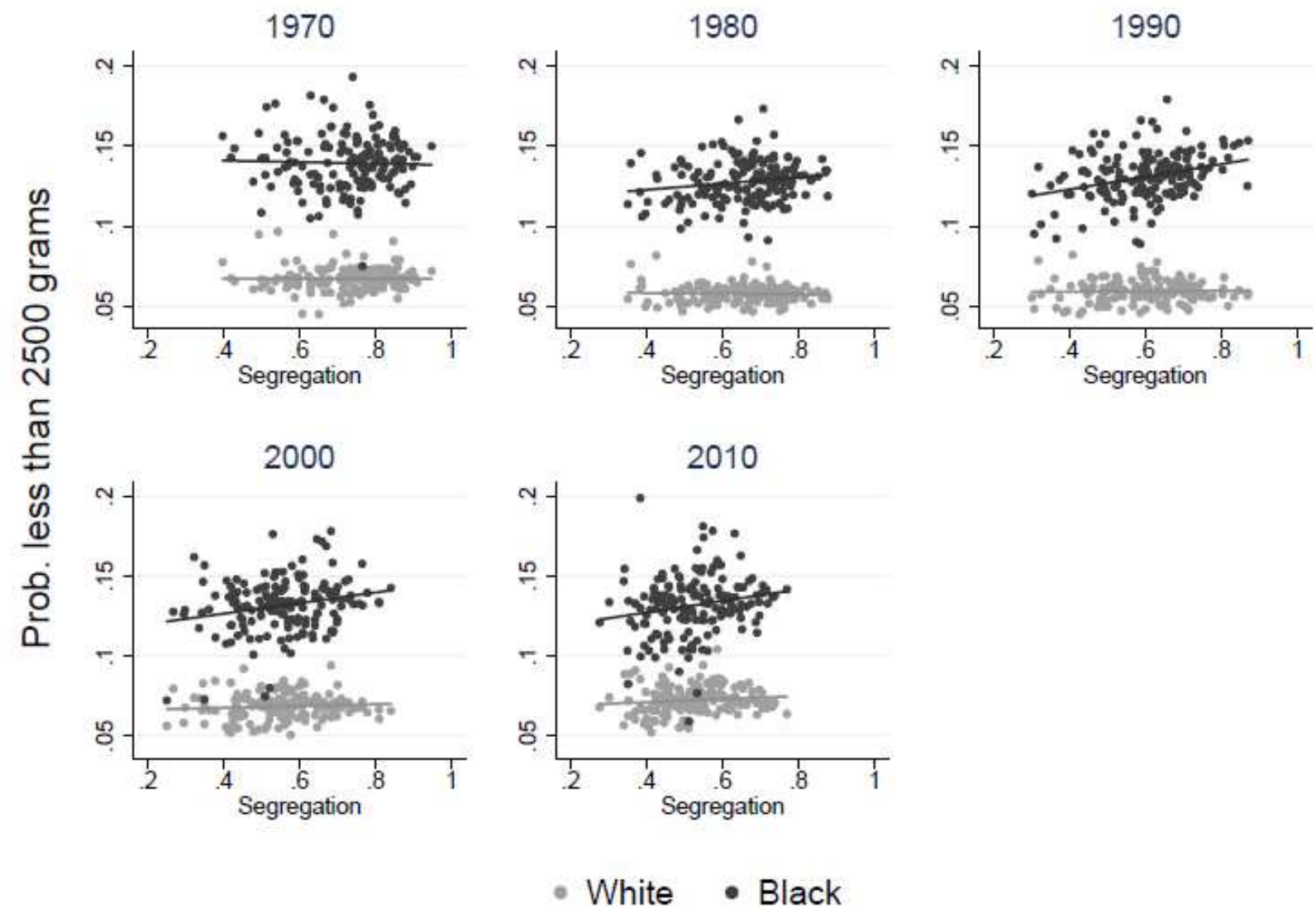

Notes: Each dot represents an MSA and plots the segregation level and proportion of low birth weight births by race. The consistent sample includes MSAs for which data exists in every year with a black population of at least 5,000. Individual birth weight data comes from the National Center for Health Statistics Natality Detail File 1970-2011. Segregation and MSA controls were created using tract-level Census data from Social Explorer (2016). 
Figure 2: MSA-level of segregation in 1970 and 2010

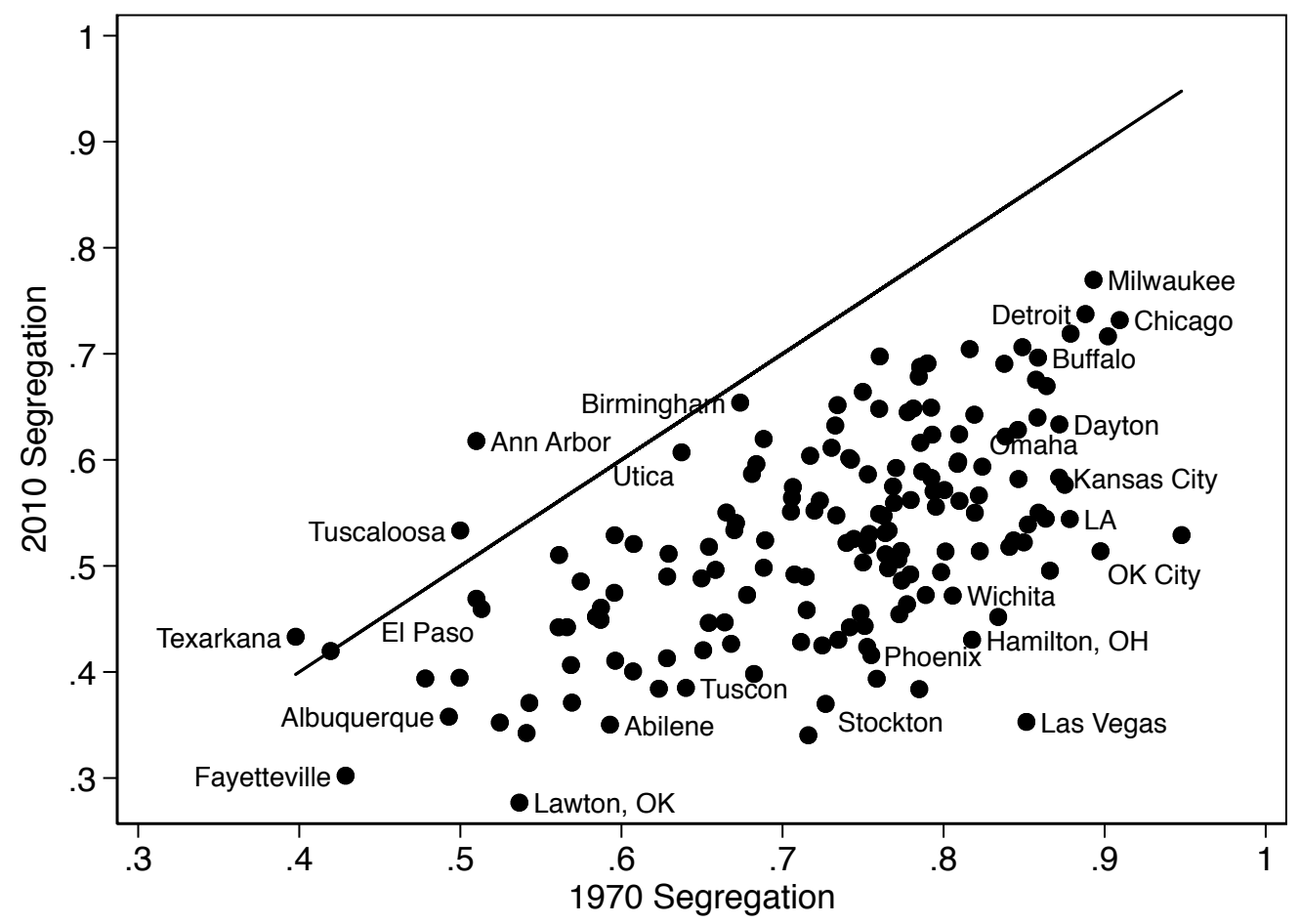

Notes: Segregation is measured using the dissimilarity index across census tracts, and was created using tract-level Census data from Social Explorer (2016). 
Figure 3: Segregation coefficients, with and without individual maternal characteristic controls

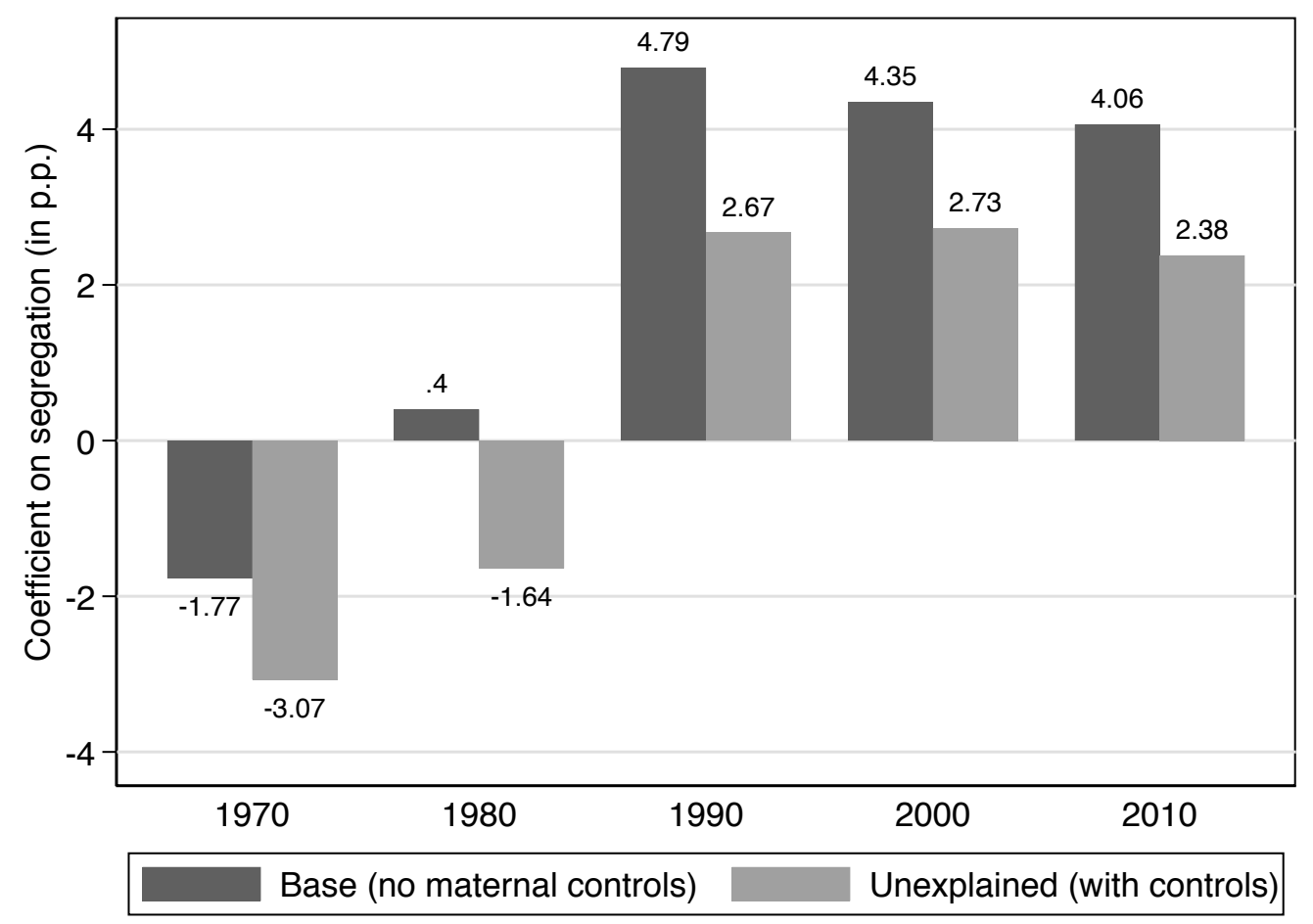

Notes: Plots are of coefficients from table 8 columns 2 and 3, and are interpreted as p.p. difference moving from a segregation index value of 0 to 1 . Base coefficients do not include individual level controls, whereas unexplained do include individual level controls. The difference between the base and unexplained coefficients can be interpreted as the portion of the segregation effect that can be "explained" by mother's marital status, education, receipt of prenatal care, age, and the birth order of the child. Individual birth weight data comes from the National Center for Health Statistics Natality Detail File 1970-2011. Segregation and MSA controls were created using tract-level Census data from Social Explorer (2016). 
Figure 4: Coefficients from decomposition of explained portion of segregation effect by year, $1970-2010$

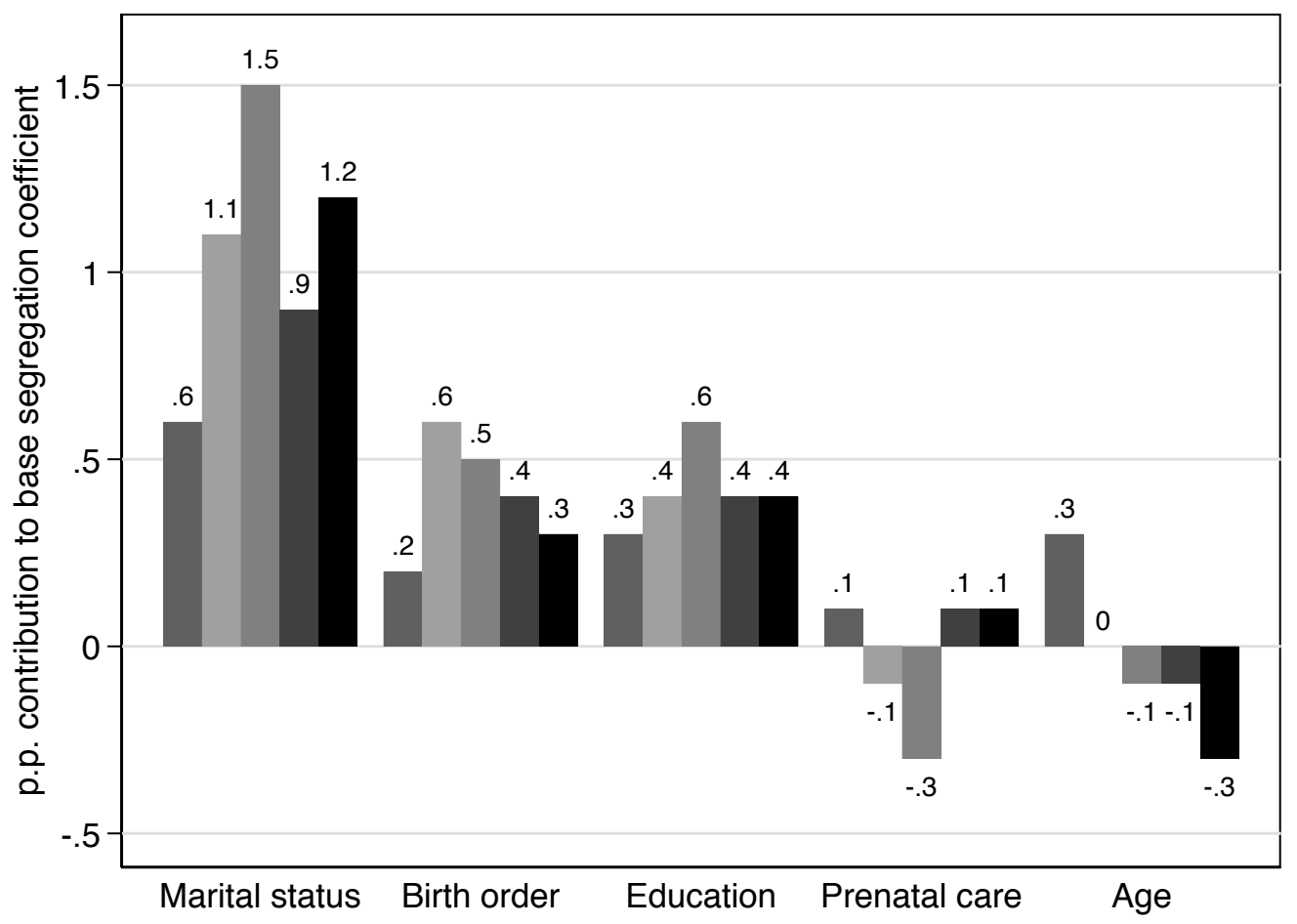

Notes: Plots are of coefficients from the decomposition of the "explained" portion of the segregation effect in 1970, 1980, 1990, 2000, and 2010 into its component parts from table 9 columns 4 through 8 . Each column within a category plots the contribution of that covariate to the full segregation effect in a given year. Individual birth weight data comes from the National Center for Health Statistics Natality Detail File 1970-2011. Segregation and MSA controls were created using tract-level Census data from Social Explorer (2016). 


\section{SUPPLEMENTAL ONLINE APPENDIX}

Table A1: Top Ten Highest Segregation MSAs

\begin{tabular}{|c|c|c|c|c|c|c|c|c|c|}
\hline 1970 & & 1980 & & 1990 & & 2000 & & 2010 & \\
\hline $\begin{array}{l}\text { Fort Lauderdale, } \\
\text { FL }\end{array}$ & 0.948 & Gary, IN & 0.877 & Detroit, MI & 0.871 & $\begin{array}{l}\text { Milwaukee- } \\
\text { Waukesha, WI }\end{array}$ & 0.777 & $\begin{array}{l}\text { Milwaukee- } \\
\text { Waukesha, WI }\end{array}$ & 0.777 \\
\hline Chicago, IL & 0.909 & $\begin{array}{l}\text { Cleveland-Lorain- } \\
\text { Elyria, } \mathrm{OH}\end{array}$ & 0.875 & Gary, IN & 0.869 & Detroit, MI & 0.732 & Detroit, MI & 0.732 \\
\hline $\begin{array}{l}\text { Cleveland-Lorain- } \\
\text { Elyria, } \mathrm{OH}\end{array}$ & 0.902 & Detroit, MI & 0.871 & $\begin{array}{l}\text { Cleveland-Lorain- } \\
\text { Elyria, } \mathrm{OH}\end{array}$ & 0.848 & Chicago, IL & 0.721 & Chicago, IL & 0.721 \\
\hline $\begin{array}{l}\text { Oklahoma City, } \\
\text { OK }\end{array}$ & 0.897 & Chicago, IL & 0.863 & Chicago, IL & 0.834 & $\begin{array}{l}\text { Cleveland-Lorain- } \\
\text { Elyria, } \mathrm{OH}\end{array}$ & 0.716 & $\begin{array}{l}\text { Cleveland-Lorain- } \\
\text { Elyria, } \mathrm{OH}\end{array}$ & 0.716 \\
\hline $\begin{array}{l}\text { Milwaukee- } \\
\text { Waukesha, WI }\end{array}$ & 0.893 & Flint, MI & 0.852 & $\begin{array}{l}\text { Milwaukee- } \\
\text { Waukesha, WI }\end{array}$ & 0.818 & Gary, IN & 0.714 & Gary, IN & 0.714 \\
\hline Detroit, MI & 0.888 & $\begin{array}{l}\text { Milwaukee- } \\
\text { Waukesha, WI }\end{array}$ & 0.833 & Flint, MI & 0.807 & $\begin{array}{l}\text { Cincinnati, OH- } \\
\text { KY-IN }\end{array}$ & 0.713 & $\begin{array}{l}\text { Cincinnati, OH- } \\
\text { KY-IN }\end{array}$ & 0.713 \\
\hline Gary, IN & 0.879 & $\begin{array}{l}\text { Fort Lauderdale, } \\
\text { FL }\end{array}$ & 0.833 & $\begin{array}{l}\text { Saginaw-Bay } \\
\text { City-Midland, MI }\end{array}$ & 0.805 & St. Louis, MO-IL & 0.707 & St. Louis, MO-IL & 0.707 \\
\hline $\begin{array}{l}\text { Los Angeles- } \\
\text { Long Beach, CA }\end{array}$ & 0.878 & $\begin{array}{l}\text { West Palm Beach- } \\
\text { Boca Raton, FL }\end{array}$ & 0.819 & $\begin{array}{l}\text { Buffalo-Niagara } \\
\text { Falls, NY }\end{array}$ & 0.804 & $\begin{array}{l}\text { Buffalo-Niagara } \\
\text { Falls, NY }\end{array}$ & 0.699 & $\begin{array}{l}\text { Benton Harbor, } \\
\text { MI }\end{array}$ & 0.702 \\
\hline Wichita, KS & 0.875 & St. Louis, MO-IL & 0.815 & Newark, NJ & 0.777 & Newark, NJ & 0.684 & $\begin{array}{l}\text { Buffalo-Niagara } \\
\text { Falls, NY }\end{array}$ & 0.699 \\
\hline $\begin{array}{l}\text { Dayton- } \\
\text { Springfield, } \mathrm{OH}\end{array}$ & 0.872 & $\begin{array}{l}\text { Saginaw-Bay } \\
\text { City-Midland, MI }\end{array}$ & 0.806 & St. Louis, MO-IL & 0.768 & $\begin{array}{l}\text { Saginaw-Bay } \\
\text { City-Midland, MI }\end{array}$ & 0.683 & Newark, NJ & 0.684 \\
\hline
\end{tabular}


Table A2: Top Ten Lowest Segregation MSAs

\begin{tabular}{|c|c|c|c|c|c|c|c|c|c|}
\hline \multirow{2}{*}{$\begin{array}{l}1970 \\
\text { Texarkana, TX- } \\
\text { AR }\end{array}$} & \multirow[b]{2}{*}{0.398} & \multicolumn{2}{|l|}{1980} & \multicolumn{2}{|l|}{1990} & \multicolumn{2}{|l|}{2000} & \multicolumn{2}{|l|}{2010} \\
\hline & & Fayetteville, NC & 0.351 & Fayetteville, NC & 0.302 & Albuquerque, NM & 0.241 & Albuquerque, NM & 0.241 \\
\hline $\begin{array}{l}\text { Greenville- } \\
\text { Spartanburg- } \\
\text { Anderson, SC }\end{array}$ & 0.419 & Albuquerque, NM & 0.359 & San Jose, CA & 0.307 & San Jose, CA & 0.247 & $\begin{array}{l}\text { Orange County, } \\
\text { CA }\end{array}$ & 0.242 \\
\hline Fayetteville, NC & 0.429 & $\begin{array}{l}\text { Texarkana, TX- } \\
\text { AR }\end{array}$ & 0.383 & Albuquerque, NM & 0.319 & Lawton, OK & 0.248 & Ventura, CA & 0.244 \\
\hline Lynchburg, VA & 0.478 & $\begin{array}{l}\text { Vineland- } \\
\text { Millville- } \\
\text { Bridgeton, NJ }\end{array}$ & 0.386 & Lawton, OK & 0.325 & Fayetteville, NC & 0.289 & Yolo, CA & 0.246 \\
\hline Albuquerque, NM & 0.493 & Lawton, OK & 0.388 & Tucson, AZ & 0.350 & $\begin{array}{l}\text { Santa Barbara- } \\
\text { Santa Maria- } \\
\text { Lompoc, CA }\end{array}$ & 0.290 & San Jose, CA & 0.247 \\
\hline $\begin{array}{l}\text { Santa Barbara- } \\
\text { Santa Maria- } \\
\text { Lompoc, CA }\end{array}$ & 0.500 & $\begin{array}{l}\text { Santa Barbara- } \\
\text { Santa Maria- } \\
\text { Lompoc, CA }\end{array}$ & 0.398 & $\begin{array}{l}\text { Vineland- } \\
\text { Millville- } \\
\text { Bridgeton, NJ }\end{array}$ & 0.362 & Tucson, AZ & 0.293 & Lawton, OK & 0.248 \\
\hline Tuscaloosa, AL & 0.500 & San Jose, CA & 0.403 & $\begin{array}{l}\text { Santa Barbara- } \\
\text { Santa Maria- } \\
\text { Lompoc, CA }\end{array}$ & 0.366 & $\begin{array}{l}\text { Corpus Christi, } \\
\text { TX }\end{array}$ & 0.304 & Jacksonville, NC & 0.254 \\
\hline Ann Arbor, MI & 0.510 & $\begin{array}{l}\text { Colorado Springs, } \\
\mathrm{CO}\end{array}$ & 0.426 & Abilene, TX & 0.375 & Abilene, TX & 0.308 & Modesto, CA & 0.255 \\
\hline $\begin{array}{l}\text { Champaign- } \\
\text { Urbana, IL }\end{array}$ & 0.510 & Lynchburg, VA & 0.429 & Gainesville, FL & 0.386 & $\begin{array}{l}\text { Phoenix-Mesa, } \\
\text { AZ }\end{array}$ & 0.312 & Reno, NV & 0.256 \\
\hline El Paso, TX & 0.513 & Tucson, AZ & 0.449 & Lynchburg, VA & 0.395 & $\begin{array}{l}\text { Stockton-Lodi, } \\
\text { CA }\end{array}$ & 0.314 & Victoria, TX & 0.260 \\
\hline
\end{tabular}


TABLE A3: MSAs with Highest Rates of Low Birth Weight and Black-White Gap

\begin{tabular}{|c|c|c|c|c|c|c|c|c|}
\hline & Highest Black LBW & $\begin{array}{l}\% \\
\text { black } \\
\text { Ibw } \\
\end{array}$ & Highest White LBW & $\begin{array}{l}\% \\
\text { white } \\
\text { lbw }\end{array}$ & $\begin{array}{l}\text { Largest Black-White } \\
\text { Gap in LBW }\end{array}$ & $\begin{array}{l}\% \\
\text { black } \\
\text { Ibw } \\
\end{array}$ & $\begin{array}{l}\% \\
\text { white } \\
\text { lbw }\end{array}$ & $\begin{array}{l}\text { black- } \\
\text { white } \\
\text { gap }\end{array}$ \\
\hline \multicolumn{9}{|l|}{1970} \\
\hline & $\begin{array}{l}\text { Providence-Warwick- } \\
\text { Pawtucket, RI }\end{array}$ & 0.193 & Colorado Springs, CO & 0.097 & $\begin{array}{l}\text { Providence-Warwick- } \\
\text { Pawtucket, RI }\end{array}$ & 0.193 & 0.070 & 0.124 \\
\hline & Salinas, CA & 0.182 & Asheville, NC & 0.095 & Salinas, CA & 0.182 & 0.058 & 0.124 \\
\hline & $\begin{array}{l}\text { Allentown-Bethlehem- } \\
\text { Easton, PA }\end{array}$ & 0.179 & Albuquerque, NM & 0.095 & $\begin{array}{l}\text { Allentown-Bethlehem- } \\
\text { Easton, PA }\end{array}$ & 0.179 & 0.066 & 0.113 \\
\hline & Lawton, OK & 0.177 & Denver, CO & 0.091 & Lawton, OK & 0.177 & 0.066 & 0.111 \\
\hline & Lubbock,TX & 0.176 & Jersey City, NJ & 0.083 & Lima, $\mathrm{OH}$ & 0.170 & 0.059 & 0.111 \\
\hline \multicolumn{9}{|l|}{1980} \\
\hline & $\begin{array}{l}\text { Huntington-Ashland, } \\
\text { WV-KY-OH }\end{array}$ & 0.174 & Colorado Springs, CO & 0.082 & $\begin{array}{l}\text { Huntington-Ashland, } \\
\text { WV-KY-OH }\end{array}$ & 0.174 & 0.059 & 0.115 \\
\hline & Racine, WI & 0.167 & Denver, CO & 0.078 & Racine, WI & 0.167 & 0.053 & 0.114 \\
\hline & Jackson, MI & 0.157 & Albuquerque, NM & 0.076 & Jackson, MI & 0.157 & 0.056 & 0.101 \\
\hline & Wichita Falls, TX & 0.153 & Amarillo, TX & 0.075 & Wichita Falls, TX & 0.153 & 0.057 & 0.097 \\
\hline & Waco, TX & 0.153 & Asheville, NC & 0.068 & $\begin{array}{l}\text { Davenport-Moline- } \\
\text { Rock Island, IA-IL }\end{array}$ & 0.145 & 0.051 & 0.093 \\
\hline \multicolumn{9}{|l|}{1990} \\
\hline & $\begin{array}{l}\text { Huntington-Ashland, } \\
\text { WV-KY-OH }\end{array}$ & 0.175 & Colorado Springs, CO & 0.082 & $\begin{array}{l}\text { Huntington-Ashland, } \\
\text { WV-KY-OH }\end{array}$ & 0.175 & 0.066 & 0.109 \\
\hline & Amarillo, TX & 0.167 & Amarillo, TX & 0.075 & $\begin{array}{l}\text { Bryan-College Station, } \\
\text { TX }\end{array}$ & 0.146 & 0.045 & 0.100 \\
\hline & Canton-Massillon, $\mathrm{OH}$ & 0.166 & Denver, CO & 0.074 & Pittsburgh, PA & 0.159 & 0.059 & 0.100 \\
\hline & Denver, CO & 0.162 & Albuquerque, NM & 0.072 & Stockton-Lodi, CA & 0.152 & 0.053 & 0.099 \\
\hline & El Paso, TX & 0.160 & $\begin{array}{l}\text { Canton-Massillon, } \\
\mathrm{OH}\end{array}$ & 0.072 & Monroe, LA & 0.145 & 0.048 & 0.097 \\
\hline \multicolumn{9}{|l|}{2000} \\
\hline & Chattanooga, TN-GA & 0.178 & Chattanooga, TN-GA & 0.093 & $\begin{array}{l}\text { Waterloo-Cedar Falls, } \\
\text { IA }\end{array}$ & 0.170 & 0.060 & 0.110 \\
\hline & Tuscaloosa, AL & 0.176 & Charleston, WV & 0.085 & Tuscaloosa, AL & 0.176 & 0.070 & 0.106 \\
\hline & Lima, $\mathrm{OH}$ & 0.175 & $\begin{array}{l}\text { Huntington-Ashland, } \\
\text { WV-KY-OH }\end{array}$ & 0.084 & Mansfield, $\mathrm{OH}$ & 0.169 & 0.069 & 0.101 \\
\hline & Tucson, AZ & 0.170 & Texarkana, TX-AR & 0.084 & Lima, OH & 0.175 & 0.075 & 0.099 \\
\hline & Waterloo-Cedar Falls, IA & 0.170 & Colorado Springs, CO & 0.084 & Tucson, AZ & 0.170 & 0.074 & 0.096 \\
\hline \multicolumn{9}{|l|}{2010} \\
\hline & Lubbock, TX & 0.208 & $\begin{array}{l}\text { Huntington- } \\
\text { Asheland, WV-KY-OH }\end{array}$ & 0.104 & Lubbock, TX & 0.208 & 0.083 & 0.125 \\
\hline & $\begin{array}{l}\text { Shreveport-Bossier City, } \\
\text { LA }\end{array}$ & 0.182 & $\begin{array}{l}\text { Shreveport-Bossier } \\
\text { City, LA }\end{array}$ & 0.095 & $\begin{array}{l}\text { Waterloo-Cedar Falls, } \\
\text { IA }\end{array}$ & 0.176 & 0.067 & 0.109 \\
\hline & Chattanooga, TN & 0.180 & Colorado Springs, CO & 0.090 & Chattanooga, TN-GA & 0.180 & 0.082 & 0.098 \\
\hline & Jackson, MS & 0.179 & El Paso, TX & 0.090 & Jackson, MS & 0.179 & 0.087 & 0.091 \\
\hline & Waterloo-Cedar Falls, IA & 0.176 & Charleston, WV & 0.087 & $\begin{array}{l}\text { Bryan-College Station, } \\
\text { TX }\end{array}$ & 0.146 & 0.056 & 0.090 \\
\hline
\end{tabular}




\section{TABLE A4: MSAs with Lowest Rates of Low Birth Weight and Black-White Gap}

\begin{tabular}{|c|c|c|c|c|c|c|c|c|}
\hline & Lowest Black LBW & $\begin{array}{l}\% \\
\text { black } \\
\text { lbw }\end{array}$ & Lowest White LBW & $\begin{array}{l}\% \\
\text { white } \\
\text { lbw }\end{array}$ & $\begin{array}{l}\text { Smallest Black-White } \\
\text { Gap in LBW }\end{array}$ & $\begin{array}{l}\% \\
\text { black } \\
\text { lbw }\end{array}$ & $\begin{array}{l}\text { \% } \\
\text { white } \\
\text { lbw }\end{array}$ & $\begin{array}{l}\text { black- } \\
\text { white } \\
\text { gap }\end{array}$ \\
\hline \multicolumn{9}{|l|}{1970} \\
\hline & Lancaster, PA & 0.075 & Tallahassee, FL & 0.045 & Lancaster, PA & 0.075 & 0.059 & 0.016 \\
\hline & $\begin{array}{l}\text { Vallejo-Fairfield-Napa, } \\
\text { CA }\end{array}$ & 0.105 & Gainesville, FL & 0.045 & Colorado Springs, CO & 0.134 & 0.097 & 0.037 \\
\hline & Tallahassee, FL & 0.106 & $\begin{array}{l}\text { Bryan-College } \\
\text { Station, TX }\end{array}$ & 0.052 & Des Moines, IA & 0.110 & 0.070 & 0.040 \\
\hline & $\begin{array}{l}\text { Evansville-Henderson, } \\
\text { IN-KY }\end{array}$ & 0.107 & Albany, GA & 0.053 & Columbus, GA-AL & 0.115 & 0.073 & 0.041 \\
\hline & $\begin{array}{l}\text { Santa Barbara-Santa } \\
\text { Maria-Lompoc, CA }\end{array}$ & 0.109 & $\begin{array}{l}\text { Grand Rapids- } \\
\text { Muskegon-Holland, } \\
\text { MI }\end{array}$ & 0.055 & Amarillo, TX & 0.120 & 0.079 & 0.041 \\
\hline \multicolumn{9}{|l|}{1980} \\
\hline & Muncie, IN & 0.091 & $\begin{array}{l}\text { Portland-Vancouver, } \\
\text { OR-WA }\end{array}$ & 0.047 & Muncie, IN & 0.091 & 0.051 & 0.040 \\
\hline & Lancaster, PA & 0.093 & Gainesville, FL & 0.047 & Wilmington, NC & 0.102 & 0.062 & 0.040 \\
\hline & $\begin{array}{l}\text { Vallejo-Fairfield-Napa, } \\
\text { CA }\end{array}$ & 0.098 & $\begin{array}{l}\text { Waterloo-Cedar } \\
\text { Falls, IA }\end{array}$ & 0.047 & Lawton, OK & 0.106 & 0.063 & 0.043 \\
\hline & $\begin{array}{l}\text { Seattle-Bellevue- } \\
\text { Everett, WA }\end{array}$ & 0.102 & $\begin{array}{l}\text { Seattle-Bellevue- } \\
\text { Everett, WA }\end{array}$ & 0.048 & Lancaster, PA & 0.093 & 0.049 & 0.044 \\
\hline & Wilmington, NC & 0.102 & Fort Wayne, IN & 0.048 & $\begin{array}{l}\text { Vallejo-Fairfield-Napa, } \\
\text { CA }\end{array}$ & 0.098 & 0.052 & 0.047 \\
\hline \multicolumn{9}{|l|}{1990} \\
\hline & Salinas, CA & 0.087 & Salinas, CA & 0.045 & Fort Smith, AR-OK & 0.093 & 0.063 & 0.029 \\
\hline & Fort Smith, AR-OK & 0.093 & $\begin{array}{l}\text { Minneapolis-St. Paul, } \\
\text { MN-WI }\end{array}$ & 0.045 & Topeka, KS & 0.103 & 0.064 & 0.039 \\
\hline & $\begin{array}{l}\text { Santa Barbara-Santa } \\
\text { Maria-Lompoc, CA }\end{array}$ & 0.095 & $\begin{array}{l}\text { Bryan-College } \\
\text { Station, TX }\end{array}$ & 0.045 & Salinas, CA & 0.087 & 0.045 & 0.042 \\
\hline & San Jose, CA & 0.095 & Gainesville, FL & 0.046 & Lawton, OK & 0.103 & 0.060 & 0.043 \\
\hline & $\begin{array}{l}\text { Vallejo-Fairfield-Napa, } \\
\text { CA }\end{array}$ & 0.099 & San Jose, CA & 0.046 & $\begin{array}{l}\text { Santa Barbara-Santa } \\
\text { Maria-Lompoc, CA }\end{array}$ & 0.095 & 0.049 & 0.045 \\
\hline \multicolumn{9}{|l|}{2000} \\
\hline & San Jose, CA & 0.071 & Lancaster, PA & 0.046 & $\begin{array}{l}\text { Waterloo-Cedar Falls, } \\
\text { IA }\end{array}$ & 0.170 & 0.060 & 0.110 \\
\hline & $\begin{array}{l}\text { Santa Barbara-Santa } \\
\text { Maria-Lompoc, CA }\end{array}$ & 0.076 & $\begin{array}{l}\text { Vallejo-Fairfield- } \\
\text { Napa, CA }\end{array}$ & 0.051 & Tuscaloosa, AL & 0.176 & 0.070 & 0.106 \\
\hline & Salinas, CA & 0.077 & Gainesville, FL & 0.051 & Mansfield, $\mathrm{OH}$ & 0.169 & 0.069 & 0.101 \\
\hline & Fort Smith, AR-OK & 0.080 & $\begin{array}{l}\text { Seattle-Bellevue- } \\
\text { Everett, WA }\end{array}$ & 0.053 & Lima, $\mathrm{OH}$ & 0.175 & 0.075 & 0.099 \\
\hline & $\begin{array}{l}\text { Seattle-Bellevue- } \\
\text { Everett, WA }\end{array}$ & 0.102 & $\begin{array}{l}\text { Portland-Vancouver, } \\
\text { OR-WA }\end{array}$ & 0.054 & Tucson, AZ & 0.170 & 0.074 & 0.096 \\
\hline \multicolumn{9}{|l|}{2010} \\
\hline & Salinas, CA & 0.050 & $\begin{array}{l}\text { Vallejo-Fairfield- } \\
\text { Napa, CA }\end{array}$ & 0.052 & Salinas, CA & 0.050 & 0.054 & -0.004 \\
\hline & Terre Haute, IN & 0.077 & Salinas, CA & 0.054 & Terre Haute, IN & 0.077 & 0.075 & 0.002 \\
\hline & Salinas, CA & 0.085 & $\begin{array}{l}\text { Seattle-Bellevue- } \\
\text { Everett, WA }\end{array}$ & 0.055 & San Jose, CA & 0.085 & 0.062 & 0.023 \\
\hline & San Jose, CA & 0.089 & Tacoma, WA & 0.055 & Abilene, TX & 0.105 & 0.081 & 0.024 \\
\hline & Tucson, AZ & 0.100 & $\begin{array}{l}\text { Portland-Vancouver, } \\
\text { OR-WA }\end{array}$ & 0.056 & Tucson, AZ & 0.100 & 0.067 & 0.032 \\
\hline
\end{tabular}


Table A5: Segregation and Low Birth Weight, 1970-2010: Alternative Weight Cut-offs

\begin{tabular}{|c|c|c|c|c|c|c|}
\hline \multicolumn{7}{|l|}{ Consistent Sample } \\
\hline & $\underline{\text { Less } 1000}$ & $\underline{\text { Less } 1500}$ & $\underline{\text { Less } 2000}$ & $\underline{\text { Less } 2,500}$ & $\underline{\text { Less } 3000}$ & Cont. Weight \\
\hline \multirow[t]{2}{*}{ Segregation x Black x 2010} & $0.0080 * * *$ & $0.0138 * * *$ & $0.0204 * * *$ & $0.0395 * * *$ & $0.0857 * *$ & $-119.2844^{*}$ \\
\hline & $(0.0030)$ & $(0.0042)$ & $(0.0062)$ & $(0.0141)$ & $(0.0399)$ & $(64.4261)$ \\
\hline \multirow[t]{2}{*}{ Segregation x Black x 2000} & 0.0037 & $0.0079 * *$ & $0.0181 * * *$ & $0.0316^{* *}$ & 0.0593 & -110.8486 \\
\hline & $(0.0031)$ & $(0.0040)$ & $(0.0066)$ & $(0.0155)$ & $(0.0402)$ & $(80.3639)$ \\
\hline \multirow[t]{2}{*}{ Segregation x Black x 1990} & 0.0007 & $0.0077 * *$ & $0.0133 * *$ & $0.0370 * * *$ & $0.0696^{*}$ & $-116.8804 *$ \\
\hline & $(0.0031)$ & $(0.0039)$ & $(0.0059)$ & $(0.0132)$ & $(0.0357)$ & $(65.5774)$ \\
\hline \multirow[t]{2}{*}{ Segregation x Black x 1980} & -0.0006 & -0.0007 & -0.0008 & 0.0083 & 0.0402 & -110.2484 \\
\hline & $(0.0044)$ & $(0.0061)$ & $(0.0080)$ & $(0.0154)$ & $(0.0395)$ & $(76.7142)$ \\
\hline \multirow[t]{2}{*}{ Segregation x Black x 1970} & -0.0001 & 0.0037 & 0.0054 & 0.0102 & 0.0203 & -89.2795 \\
\hline & $(0.0031)$ & $(0.0047)$ & $(0.0067)$ & $(0.0134)$ & $(0.0356)$ & $(65.1804)$ \\
\hline \multirow[t]{2}{*}{ Segregation x 2010} & 0.0008 & 0.0029 & $0.0066^{*}$ & $0.0195^{*}$ & $0.0620 *$ & -86.5977 \\
\hline & $(0.0009)$ & $(0.0019)$ & $(0.0039)$ & $(0.0114)$ & $(0.0354)$ & $(66.3709)$ \\
\hline \multirow[t]{2}{*}{ Segregation x 2000} & $0.0017^{*}$ & 0.0023 & 0.0037 & 0.0124 & 0.0233 & -25.7920 \\
\hline & $(0.0009)$ & $(0.0016)$ & $(0.0035)$ & $(0.0121)$ & $(0.0437)$ & $(86.7646)$ \\
\hline \multirow[t]{2}{*}{ Segregation x 1990} & $0.0016^{*}$ & 0.0023 & 0.0042 & 0.0084 & 0.0043 & 14.3659 \\
\hline & $(0.0009)$ & $(0.0017)$ & $(0.0034)$ & $(0.0089)$ & $(0.0310)$ & $(59.8989)$ \\
\hline \multirow[t]{2}{*}{ Segregation x 1980} & 0.0007 & 0.0011 & 0.0012 & -0.0003 & -0.0141 & 54.8004 \\
\hline & $(0.0007)$ & $(0.0010)$ & $(0.0022)$ & $(0.0081)$ & $(0.0317)$ & $(62.3384)$ \\
\hline \multirow[t]{2}{*}{ Segregation x 1970} & 0.0014 & 0.0010 & 0.0018 & 0.0012 & -0.0056 & 54.9806 \\
\hline & $(0.0010)$ & $(0.0015)$ & $(0.0024)$ & $(0.0088)$ & $(0.0321)$ & $(57.2952)$ \\
\hline Observations & $20,884,335$ & $20,884,335$ & $20,884,335$ & $20,884,335$ & $20,884,335$ & $20,884,335$ \\
\hline
\end{tabular}

Notes: $* * * \mathrm{p}<0.01, * * \mathrm{p}<0.05, * \mathrm{p}<0.1$. Standard errors adjusted for clustering at the MSA $\mathrm{x}$ YEAR level are in parentheses. The specification matches column 6 of table 2. Each regression includes MSA x Year controls (percent manufacturing, log population, percent black, average family income) and Region x Year fixed effects, both interacted with our Black indicator variable. Individual birth weight data comes from the National Center for Health Statistics Natality Detail File 1970-2011. Segregation and MSA controls were created using tract-level Census data from Social Explorer (2016). 
Table A6: Segregation and low birth weight: segregation percentiles

\begin{tabular}{|c|c|c|c|c|c|c|c|}
\hline & \multicolumn{5}{|c|}{ Full Sample } & \multicolumn{2}{|c|}{ Consistent Sample } \\
\hline & $(1)$ & $(2)$ & (3) & $(4)$ & $(5)$ & $(6)$ & (7) \\
\hline $\begin{array}{c}\text { Segregation x Black } \\
2010\end{array}$ & $\begin{array}{c}0.0052 \\
(0.0035)\end{array}$ & $\begin{array}{c}0.0107 * * * \\
(0.0036)\end{array}$ & $\begin{array}{l}0.0101^{* *} \\
(0.0050)\end{array}$ & $\begin{array}{c}0.0142 * * * \\
(0.0046)\end{array}$ & $\begin{array}{c}0.0157 * * * \\
(0.0033)\end{array}$ & $\begin{array}{c}0.0119^{* *} \\
(0.0056)\end{array}$ & $\begin{array}{c}0.0142 * * * \\
(0.0039)\end{array}$ \\
\hline 2000 & $\begin{array}{c}0.0041 \\
(0.0048)\end{array}$ & $\begin{array}{c}0.0071^{* *} \\
(0.0036)\end{array}$ & $\begin{array}{c}0.0056 \\
(0.0052)\end{array}$ & $\begin{array}{c}0.0085 \\
(0.0054)\end{array}$ & $\begin{array}{c}0.0093 * * \\
(0.0043)\end{array}$ & $\begin{array}{c}0.0068 \\
(0.0065)\end{array}$ & $\begin{array}{l}0.0086^{*} \\
(0.0051)\end{array}$ \\
\hline 1990 & $\begin{array}{c}0.0241 * * * \\
(0.0039)\end{array}$ & $\begin{array}{c}0.0172 * * * \\
(0.0035)\end{array}$ & $\begin{array}{c}0.0220 * * * \\
(0.0045)\end{array}$ & $\begin{array}{c}0.0121 * * * \\
(0.0045)\end{array}$ & $\begin{array}{c}0.0121 * * * \\
(0.0040)\end{array}$ & $\begin{array}{l}0.0107 * \\
(0.0056)\end{array}$ & $\begin{array}{c}0.0104 * * \\
(0.0048)\end{array}$ \\
\hline 1980 & $\begin{array}{c}0.0122 * * * \\
(0.0044)\end{array}$ & $\begin{array}{c}0.0090^{* *} \\
(0.0043)\end{array}$ & $\begin{array}{c}0.0074 * * \\
(0.0035)\end{array}$ & $\begin{array}{c}0.0046 \\
(0.0052)\end{array}$ & $\begin{array}{c}0.0054 \\
(0.0049)\end{array}$ & $\begin{array}{c}0.0003 \\
(0.0062)\end{array}$ & $\begin{array}{c}0.0005 \\
(0.0057)\end{array}$ \\
\hline 1970 & $\begin{array}{c}0.0042 \\
(0.0038)\end{array}$ & $\begin{array}{l}-0.0007 \\
(0.0039)\end{array}$ & $\begin{array}{c}0.0053 \\
(0.0038)\end{array}$ & $\begin{array}{c}0.0061 \\
(0.0048)\end{array}$ & $\begin{array}{l}0.0076^{*} \\
(0.0043)\end{array}$ & $\begin{array}{c}0.0047 \\
(0.0049)\end{array}$ & $\begin{array}{c}0.0056 \\
(0.0043)\end{array}$ \\
\hline $\begin{array}{l}\text { Segregation } \\
2010\end{array}$ & $\begin{array}{c}0.0054 * * * \\
(0.0019)\end{array}$ & $\begin{array}{c}0.0075 * * * \\
(0.0021)\end{array}$ & $\begin{array}{c}0.0026 \\
(0.0031)\end{array}$ & $\begin{array}{c}0.0082 * * \\
(0.0039)\end{array}$ & $\begin{array}{c}0.0017 \\
(0.0021)\end{array}$ & $\begin{array}{c}0.0094 * * \\
(0.0047)\end{array}$ & $\begin{array}{c}0.0023 \\
(0.0023)\end{array}$ \\
\hline 2000 & $\begin{array}{c}0.0040 * * \\
(0.0018)\end{array}$ & $\begin{array}{c}0.0068 * * * \\
(0.0019)\end{array}$ & $\begin{array}{c}0.0006 \\
(0.0032)\end{array}$ & $\begin{array}{c}0.0065 \\
(0.0041)\end{array}$ & $\begin{array}{c}0.0021 \\
(0.0019)\end{array}$ & $\begin{array}{c}0.0064 \\
(0.0053)\end{array}$ & $\begin{array}{c}0.0018 \\
(0.0022)\end{array}$ \\
\hline 1990 & $\begin{array}{c}0.0002 \\
(0.0018)\end{array}$ & $\begin{array}{c}0.0017 \\
(0.0014)\end{array}$ & $\begin{array}{l}-0.0013 \\
(0.0025)\end{array}$ & $\begin{array}{c}0.0020 \\
(0.0029)\end{array}$ & $\begin{array}{l}-0.0007 \\
(0.0017)\end{array}$ & $\begin{array}{c}0.0035 \\
(0.0038)\end{array}$ & $\begin{array}{c}0.0007 \\
(0.0020)\end{array}$ \\
\hline 1980 & $\begin{array}{c}0.0003 \\
(0.0018)\end{array}$ & $\begin{array}{c}0.0017 \\
(0.0015)\end{array}$ & $\begin{array}{l}-0.0001 \\
(0.0018)\end{array}$ & $\begin{array}{c}0.0006 \\
(0.0025)\end{array}$ & $\begin{array}{c}-0.0005 \\
(0.0019)\end{array}$ & $\begin{array}{c}0.0004 \\
(0.0028)\end{array}$ & $\begin{array}{c}0.0000 \\
(0.0021)\end{array}$ \\
\hline 1970 & $\begin{array}{l}-0.0023 \\
(0.0026)\end{array}$ & $\begin{array}{l}-0.0021 \\
(0.0032)\end{array}$ & $\begin{array}{l}-0.0003 \\
(0.0025)\end{array}$ & $\begin{array}{c}0.0007 \\
(0.0032)\end{array}$ & $\begin{array}{c}0.0001 \\
(0.0018)\end{array}$ & $\begin{array}{c}0.0009 \\
(0.0033)\end{array}$ & $\begin{array}{c}0.0011 \\
(0.0018)\end{array}$ \\
\hline MSA-Year Controls & No & Yes & No & Yes & Yes & Yes & Yes \\
\hline Region-Year Fixed Effects & No & No & Yes & Yes & Yes & Yes & Yes \\
\hline MSA Fixed Effects & No & No & No & No & Yes & No & Yes \\
\hline Observations & $25,041,094$ & $25,041,094$ & $25,041,094$ & $25,041,094$ & $25,041,094$ & $20,884,335$ & $20,884,335$ \\
\hline
\end{tabular}


TABLE A7: Segregation and Low Birth Weight, 1970-2000 - Isolation Index

\begin{tabular}{|c|c|c|c|c|c|c|c|}
\hline & \multicolumn{5}{|c|}{ Full Sample } & \multicolumn{2}{|c|}{ Consistent Sample } \\
\hline & $(1)$ & $(2)$ & (3) & (4) & (5) & $(6)$ & (7) \\
\hline \multirow[t]{2}{*}{ Segregation x Black x 2010} & $0.0245 * * *$ & $0.0355 * * *$ & $0.0273 * * *$ & $0.0529 * * *$ & $0.0571 * * *$ & $0.0511 * * *$ & $0.0572 * * *$ \\
\hline & $(0.0060)$ & $(0.0085)$ & $(0.0067)$ & $(0.0101)$ & $(0.0090)$ & $(0.0114)$ & $(0.0099)$ \\
\hline \multirow[t]{2}{*}{ Segregation x Black x 2000} & $0.0199 * * *$ & $0.0253 * * *$ & $0.0227 * * *$ & $0.0386^{* * *}$ & $0.0419 * * *$ & $0.0371 * * *$ & $0.0433 * * *$ \\
\hline & $(0.0062)$ & $(0.0087)$ & $(0.0066)$ & $(0.0110)$ & $(0.0096)$ & $(0.0133)$ & $(0.0114)$ \\
\hline \multirow[t]{2}{*}{ Segregation x Black x 1990} & $0.0387 * * *$ & $0.0381 * * *$ & $0.0448 * * *$ & $0.0374 * * *$ & $0.0382 * * *$ & $0.0378 * * *$ & $0.0390 * * *$ \\
\hline & $(0.0054)$ & $(0.0068)$ & $(0.0060)$ & $(0.0105)$ & $(0.0097)$ & $(0.0133)$ & $(0.0123)$ \\
\hline \multirow[t]{2}{*}{ Segregation x Black x 1980} & $0.0222 * * *$ & $0.0205 * *$ & $0.0163 * * *$ & 0.0115 & 0.0135 & 0.0027 & 0.0058 \\
\hline & $(0.0077)$ & $(0.0090)$ & $(0.0059)$ & $(0.0103)$ & $(0.0095)$ & $(0.0123)$ & $(0.0112)$ \\
\hline \multirow[t]{2}{*}{ Segregation x Black x 1970} & 0.0016 & -0.0021 & 0.0033 & 0.0091 & 0.0132 & 0.0059 & 0.0098 \\
\hline & $(0.0068)$ & $(0.0075)$ & $(0.0058)$ & $(0.0097)$ & $(0.0088)$ & $(0.0101)$ & $(0.0091)$ \\
\hline \multirow[t]{2}{*}{ Segregation x 2010} & $0.0081 * *$ & $0.0151 * * *$ & -0.0032 & $0.0155^{* *}$ & -0.0019 & $0.0181 * *$ & 0.0012 \\
\hline & $(0.0033)$ & $(0.0049)$ & $(0.0033)$ & $(0.0064)$ & $(0.0062)$ & $(0.0071)$ & $(0.0066)$ \\
\hline \multirow[t]{2}{*}{ Segregation x 2000} & $0.0072 * *$ & $0.0167 * * *$ & -0.0022 & $0.0166^{* * *}$ & 0.0032 & $0.0186^{* *}$ & 0.0039 \\
\hline & $(0.0029)$ & $(0.0036)$ & $(0.0029)$ & $(0.0063)$ & $(0.0050)$ & $(0.0076)$ & $(0.0055)$ \\
\hline \multirow{2}{*}{ Segregation x 1990} & 0.0032 & $0.0054^{*}$ & -0.0023 & 0.0069 & -0.0020 & $0.122^{*}$ & 0.0018 \\
\hline & $(0.0025)$ & $(0.0029)$ & $(0.0031)$ & $(0.0056)$ & $(0.0045)$ & $(0.0071)$ & $(0.0052)$ \\
\hline \multirow[t]{2}{*}{ Segregation x 1980} & 0.0032 & 0.0046 & 0.0011 & 0.0037 & -0.0008 & 0.0046 & 0.0004 \\
\hline & $(0.0026)$ & $(0.0035)$ & $(0.0026)$ & $(0.0057)$ & $(0.0041)$ & $(0.0062)$ & $(0.0044)$ \\
\hline \multirow{2}{*}{ Segregation x 1970} & 0.0011 & 0.0006 & 0.0004 & 0.0044 & 0.0015 & 0.0052 & 0.0042 \\
\hline & $(0.0029)$ & $(0.0056)$ & $(0.0031)$ & $(0.0059)$ & $(0.0037)$ & $(0.0062)$ & $(0.0039)$ \\
\hline MSA-Year Controls & No & Yes & No & Yes & Yes & Yes & Yes \\
\hline Region x Year Fixed Effects & No & No & Yes & Yes & Yes & Yes & Yes \\
\hline MSA Fixed Effects & No & No & No & No & Yes & No & Yes \\
\hline Observations & $25,041,094$ & $25,041,094$ & $25,041,094$ & $25,041,094$ & $25,041,094$ & $20,884,335$ & $20,884,335$ \\
\hline
\end{tabular}

The isolation index is defined as $\sum_{i=1}^{n}\left[\left(\frac{x_{i}}{X}\right)\left(\frac{x_{i}}{t_{i}}\right)\right]$, where $x_{i}$ indicates the black population in tract i, $X$ indicates the total black population of an area, and $t_{i}$ represents the total population in tract 
Table A8: Mean values for characteristics reported on birth certificates by segregation quartile (black births only)

\begin{tabular}{lccccc} 
& \multicolumn{3}{c}{ Prenatal care } & & \\
& Married & 1st tri & Mom HS Grad & Mother's age & Birth order \\
\cline { 2 - 5 } 1970 & & & & & \\
Lowest 25th & 65.80 & 45.52 & 52.61 & 23.09 & 2.82 \\
High 25th & 57.41 & 47.15 & 52.22 & 23.14 & 2.90 \\
Diff (High - Low) & $-8.39^{* * *}$ & $1.63^{* * *}$ & -0.40 & $0.06^{* *}$ & $0.08^{* * *}$ \\
1980 & & & & \\
Lowest 25th & 52.79 & 60.85 & 67.91 & 23.47 & 2.40 \\
High 25th & 37.28 & 64.83 & 64.35 & 23.46 & 2.54 \\
Diff (High - Low) & $-15.52^{* * *}$ & $3.98^{* * *}$ & $-3.56^{* * *}$ & -0.01 & $0.14^{* * *}$ \\
1990 & & & & \\
Lowest 25th & 40.98 & 62.05 & 73.17 & 24.31 & 2.56 \\
High 25th & 27.24 & 61.60 & 67.87 & 24.59 & 2.83 \\
Diff (High - Low) & $-13.75^{* * *}$ & $-0.45^{* * *}$ & $-5.30^{* * *}$ & $0.28^{* * *}$ & $0.26^{* * *}$ \\
2000 & & & & \\
Lowest 25th & 36.03 & 75.99 & 77.45 & 24.98 & 2.59 \\
High 25th & 27.28 & 72.25 & 72.69 & 25.42 & 2.88 \\
Diff (High - Low) & $-8.75^{* * *}$ & $-3.74^{* * *}$ & $-4.76^{* * *}$ & $0.45^{* * *}$ & $0.30^{* * *}$ \\
2010 & & & & \\
Lowest 25th & 31.57 & 66.89 & 79.49 & 25.86 & 2.64 \\
High 25th & 23.47 & 63.23 & 76.08 & 26.11 & 2.96 \\
Diff (High - Low) & $-8.10^{* * *}$ & $-3.66^{* * *}$ & $-3.41^{* * *}$ & $0.25^{* * *}$ & $0.32^{* * *}$
\end{tabular}

Notes: The reported summary statistics are for all individual births within a segregation category. Low segregation is the bottom 25 percent of MSAs in a given year. High segregation is the top 25 percent of MSAs. The final row within each year reports the difference between high and low segregation areas with associated t-tests: $* * * \mathrm{p}<0.01, * * \mathrm{p}<0.05, * \mathrm{p}<0.1$. Individual birth weight data comes from the National Center for Health Statistics Natality Detail File 1970-2011. Segregation measures were created using tract-level Census data from Social Explorer (2016). 